\title{
Türkiye'de Illk ve Orta Öğretimde Özel Gereksinimli Öğrencilere Yönelik Eğitim Politikalarının İncelenmesi
}

\author{
Nihan TEMiZ1 ${ }^{1}$, Bülent YILMAZ²
}

\begin{abstract}
Öz: Temel hak ve eşitlikler ilkesinden yola çıkıldı̆̆ında eğitim politikalarının, toplumdaki her birey için kapsayıcı nitelikte olması gerekmektedir. Bu noktada eğitim politikası bileşenlerinin engeli olan ya da olmayan herkes için hak gözeten, buna uygun hedeflerle düzenlenmiş olan ve uygulamaya konulabilen özellikler göstermesi önemlidir. İçerik analizi ile gerçekleştirilen bu çalışmanın amacı, Türkiye' de halen yürürlükte olan ilk ve orta öğretim düzeyindeki eğitim politikasının özel gereksinimli bireylere ilişkin yaklaşımlarını ortaya koymak ve değerlendirmektir. Çalışmada Türkiye'de ilk ve orta öğretimde özel gereksinimli bireylere yönelik olan ve halen yürürlükte bulunan eğitim politikası belgeleri incelenmiş ve yorumlanmıştır. Bu belgeler; T.C. 1982 Anayasası, Eğitim Yasaları, Kararnameler, Yönetmelik ve Yönergeler, Kalkınma Planları, Milli Eğitim Şuraları ve eğitim çalıştaylarıdır. Çalışmanın sonuçları, özel gereksinimli bireylerin Türkiye eğitim politikalarında yeterince ele alındığına, ancak uygulamaya geçme konusunda çalışmalar ve modellemeler yapılması gerektiğine işaret etmektedir. Çalışma sonunda çeşitli önerilerde bulunulmuştur.
\end{abstract}

Anahtar Sözcükler: Politika, Eğitim Politikası, Özel Gereksinimli Birey

\section{Study of Education Policies for the Disabled Primary and Secondary Education in Turkey}

\begin{abstract}
Education policies should be inclusive and should show characteristics that are rightful, organized with appropriate goals and can be implemented for anyone with / without disabilities. Description methodology and literature review / analysis technique performed with the aim of this study is still in force and the first to reveal documents related to disability policy approaches through the concept of education policy at secondary level and is assessing in Turkey. These documents are T. R. Constitutions of 1982, Education Act, Decrees, Regulations and Guidelines, Development Plans, National Education Councils and Education Workshops. The results of he study highlights that the concept of individuals with special needs are covered adequately in education policies. However, more studies should be carried out to put these policies in practice and to create models but work on them in practice and modeling indicate that needs to be done. Various recommendations were made in the end of the study.
\end{abstract}

Keywords: Policy, Education Policy, Individual with Special Needs

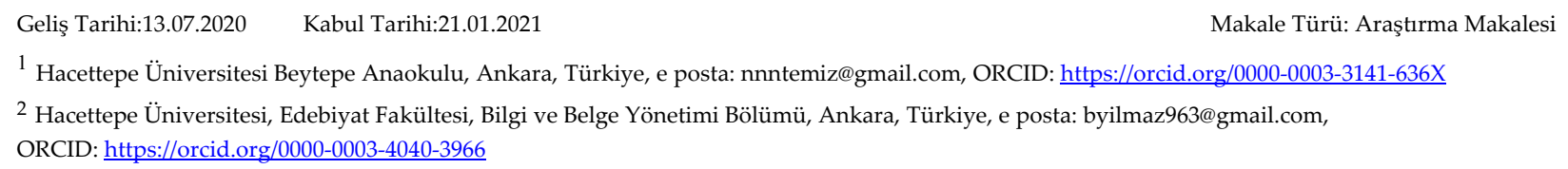

${ }^{1}$ Hacettepe Üniversitesi Beytepe Anaokulu, Ankara, Türkiye, e posta: nnntemiz@gmail.com, ORCID: https://orcid.org/0000-0003-3141-636X

2 Hacettepe Üniversitesi, Edebiyat Fakültesi, Bilgi ve Belge Yönetimi Bölümü, Ankara, Türkiye, e posta: byilmaz963@gmail.com, ORCID: https://orcid.org/0000-0003-4040-3966 
Son yıllarda özel gereksinimli bireylerin gereksinimlerine yönelik sorunlar tüm dünyada tartışılmaktadır. Türkiye'de de buna ilişkin çalışmalar yapılmakta ve gerekli politikalar oluşturulmaktadır. Ülkelerin özel gereksinim ile ilgili gerçekleştirdikleri uygulamaların temeli bu politikaların hangi başlıkları, ne şekilde ele aldığıyla yakından ilgilidir. Diğer yandan politikalar kapsamında aktarılan uygulama ve süreçlerin paylaşılabilir ve sürdürülebilir olması da önemlidir. Bu bakımdan ilgili politikaların içeriğini kapsayan politika evraklarında özel gereksinim kavramına ne kadar ve nasıl yer verildiğinin tespit edilmesi, anlamlı bir gereklilik olarak karşımıza çıkmaktadır.

Bu çalışmada kanunun kavramsal çerçevesi, "Eğitimde özel gereksinimli bireyler" ve "Özel gereksinimli bireylere yönelik eğitim politikaları" başlıkları altında aktarılmış ve Türkiye'deki özel gereksinimli olmaya ilişkin halen yürürlükte olan politika belgeleri incelenerek sonuçlar ifade edilmiştir.

\section{Eğitimde özel gereksinimli bireyler}

Birleşmiş Milletler Kurulu'nun, İnsan Hakları Bildirgesi'ne ek olarak yayımlanan 3447 sayılı Engelli Kişilerin Hakları Bildirisi'nin 1. maddesine göre özel gereksinimli birey, "kişisel ve sosyal yaşantısında kendi kendine yapması gereken işleri, bedensel veya ruhsal yeteneklerindeki, kalıtımsal ya da sonradan olma herhangi bir noksanlık sonucu yapamayanlar" şeklinde tanımlanmaktadır. Engellilerin Haklarına İlişkin Sözleşme;

-bunun gelişen bir kavram olduğuna,

-tüm insan haklarının ve temel özgürlüklerin (herhangi bir ayrımcılık yapılmadan) bu bireyler için de geçerli olduğuna,

-fırsat eşitliğine, sürdürülebilir kalkınma stratejilerinin parçası olması gerekliliğine,

-özel gereksinimli bireylerin kendi içlerindeki çeşitliliğe kabul gösterilmesine,

-her türlü destek, güçlendirme ve koruma ihtiyacına, kontrolüne, haklarına dünyanın her yerinde aynı saygının ve dikkatin gösterilmesine,

-tüm katılımlarına, kalkınmalarına, yoksulluktan kurtulmalarına katkıda bulunulmasına,

-bireysel varlık ve bağımsızlıklarına saygı gösterilmesine,

-ihmal/istismar/kötü muamele risklerine karşı korunmalarına,

-bilgiye eşit erişim, yaşam hakkı, yasa önünde diğer insanlarla eşit olma, bağımsız yaşam sürdürebilme, adalete erişebilme, düşünce ve ifade özgürlüğü, eğitim/sağlık/rehabilitasyona erişebilme, kültürel ve toplumsal yaşama katılım gibi hak ve özgürlüklere vurgu yapmakta (Milletlerarası Sözleşme, 2009) ve "özel gereksinimli olma" kavramını birbirleriyle ilişkili haklar ve özgürlükler üzerinden açıklamaktadır.

Türkiye'de 2005 yılında çıkarılan 5378 Sayılı Kanuna göre ise özel gereksinimli birey, “doğuştan veya sonradan herhangi bir nedenle bedensel, zihinsel, ruhsal, duyusal ve sosyal yeteneklerini çeşitli derecelerde kaybetmesi nedeniyle toplumsal yaşama uyum sağlama ve günlük ihtiyaçlarını karşılamada güçlükleri olan; korunma, bakım, rehabilitasyon, danışmanlık ve destek hizmetlerine ihtiyaç duyan kişi"dir (Engelliler Hakkında Kanun, 2005).

Dünya'da ve Türkiye'de geçmişten günümüze "sakat olmak", "yetersiz olmak", "özürlü olmak" ve "engelli olmak" gibi tanımlamalar ve kavram kargaşası içinde ele alınan (Başbakkal ve Bilsin, 2014, s. 66) özel gereksinimli olma kavramı ile ilgili kavramsal bir çerçeve oluşturmak ya da özel gereksinimli olmanın bireyler ve toplumlar üzerindeki etkilerini araştırmalar yoluyla anlamaya çalışmak için öncelikle bu konuda yapılan istatistiklere, raporlara ve verilere ihtiyaç duyulmaktadır. Var olan ihtiyacın belirlenmesi kaynak yönetimi, ortam düzenlemesi, organizasyon, istihdam, sağlık, eğitim vb. önemli hedeflerin sınırlarının çizilmesi için de gerekli görünmektedir. Dünya üzerinde 1 milyar kadar özel gereksinimli bireyin yaşadığı hesap edilmektedir. İktisadi İşbirliği ve Kalkınma Teşkilatı (The Organisation For Economic Co-Operation And Development $[\mathrm{OECD}])$, Avrupa Birliği (AB) ve Türkiye verilerine göre bu rakam dünya nüfusunun yaklaşık \% 15 'ine karşılık 
gelmekte, bu da özel gereksinimli bireylerin "en büyük azınlık" olarak nitelendirilmesine neden olmaktadır (Engelsiz Yaşama Derneği, 2020).

Türkiye'de özel gereksinimli bireylerle ilgili en güncel veri 2011 yılına ait Türkiye İstatistik Kurumu (TÜIK) verileridir. Buna göre Türkiye'de yaklaşık 5 milyon özel gereksinimli birey bulunmakta (nüfusun $\% 6,9^{\prime}$ u) ve 3-19 yaş arası ilk ve orta öğretimdeki çocukların özel gereksinimli nüfusun içindeki alanının \%1'den az olduğu görülmektedir (T.C. Aile Çalışma ve Sosyal Hizmetler Bakanlığı, 2012). Günümüze gelindiğinde, TÜİK'in konu ile ilgili yeni veriler eklemediği, ancak Ulusal Engelli Veri Tabanının resmi olmayan rakamlarına göre 9 milyon civarında özel gereksinimli birey olduğu ve bunun da nüfusun yaklaşık \%13'üne karş1lık geldiği belirtilmektedir. Bunların \%27'sinin 0-21 yaş, \%36'sının 22-49 yaş, \%37'sinin ise 50-64 yaş arasında olduğu bilinmektedir (Engelsiz Yaşama Derneği, 2020). Milli Eğitim Bakanlığı tarafından açıklanan “Milli Eğitim İstatistikleri-Örgün Eğitim 2018/2019" verilerine göre, örgün eğitimdeki tüm öğrencilerin 5 milyon 267 bin 378'i ilkokulda, 5 milyon 627 bin 75'i ortaokulda, 5 milyon 649 bin 594'ü ortaöğretimde bulunmaktadır. Özel eğitim kurumlarına devam eden özel gereksinimli öğrenci sayısı ise 1 milyon 440 bin 577 olup, bunun 262 bin 164'ü ilkokulda, 338 bin 46'sı ortaokulda ve 581 bin 693'ü ortaöğretimde yer almaktadır (T.C. Milli Eğitim Bakanlığı, 2019a).

Bir durumun tanımlanabilmesi ve politika haline gelebilmesi için veriler ve analizler sonucu niceliğinin hesaplanması ve sayılarla ifade edilebilmesi yeterli değildir. Kamu ve politika yapıcılar tarafından sorun olarak algılanması ve politika gündeminde yer alması gerekmektedir. Bunun için de o soruna dikkat çekiliyor olması, sorunun çözümü için hedefler belirlenebilmesi, bu hedefler doğrultusunda yol ve yöntemlerin ortaya konması ve hedeflerin öne sürdüğü ilkeler üzerinden çözüme ulaştıracak uygulamaların planlanması gerekmektedir (Aktel ve Erten, 2017, s. 166). Bu noktada özel gereksinimli olmak toplumsal bir sorun alanı olarak ortaya çıkmakta ve özel gereksinimli bireylerin farklı ihtiyaçları üzerinden politikalar oluşturulması gereği doğmaktadır. Eğitim politikaları, bu ihtiyaçların en önemlilerinden biri olarak ele alınmakta ve Trowler'ün (2003) çalışmasında da (akt. Ertuğrul, 2019) belirtildiği gibi eğitim ile nasıl bir birey yetiştirmenin hedeflendiği, özelliklerinin neler olacağı, bunu sağlamak için nasıl ortamlara ihtiyaç duyulacağı, bu amacı gerçekleştirecek öğretmenlerin sahip olması gereken niteliklerin neler olduğu ve bu niteliklerin öğretmenlere nasıl kazandırılacağı, belirlenen hedeflere ulaşılabilmesi için hangi öğretim programlarının kullanılacağı, maliyeti ve nasıl karşılanacağı, hedeflere ulaşılıp ulaşılamadığının ne şekilde değerlendirileceği üzerinde durmaktadır.

\section{Özel gereksinimli bireylere yönelik eğitim politikaları}

Eğitim politikaları "eğitim sistemine yönelik olarak belirlenen ilke, yasa ve kuralların toplamı"dır (Ertuğrul, 2019, s. 16). Bu tanım eğitim kurumlarının kuruluşu, işleyişi, kısa/orta ve uzun vadedeki hedeflerini, finansmanını, insan kaynaklarının seçimini, çalışma koşulları ve özlük hakları gibi konulara dair ilke ve kuralların bütününü kapsamına almaktadır (Uluğ, 1985, s. 85). Bu noktadan bakıldığında eğitim politikaları, "eğitim alanında bireysel ve toplumsal çıkarlara hizmet eden amaçları/hedefleri, dolayısıyla bu alana ilişkin ilke ve görevleri belirleme, bu hedeflere etkin biçimde ulaşma yollarını ortaya koyma" olarak özetlenebilecek bir içeriğe sahip görünmektedir. Eğitim politikası kavramı bunun yanı sıra eğitim ve öğretim kurumları için hukuksal temellere dayanan bir düzen oluşturmak bakımından ele alınması gereken tüm önlemleri de içermektedir (Özdem 2015, s. 632; Yılmaz, 2004, s. 31).

Bir ülkenin genel kalkınma alanları ve gelişmişlik düzeyinin belirlenmesinde eğitim politikaları önemli rol oynamakta, ancak eğitim politikalarının sadece var olmaları değil, aynı zamanda nitelikleri de önemli etkenler olarak karşımıza çıkmaktadır. Ülkedeki politika yapıcıların eğitime yaklaşımı, o ülkenin genel politik yapısı, toplumsal ve ekonomik koşulları, ulusal planlama anlayışı, dönüşüm gerektiren global değişimler (küreselleşme, çok dillilik, çok kültürlülük, yeni kavramlar, bilgi teknolojilerinin gelişmesi, demokratik açılımlar, nüfus yapılarındaki değişimler vb.) eğitim politikalarını etkilemekte ve belirlemektedir (Ertuğrul, 2019, s. 17).

Eğitim politikaları, kapsamlarında kamuyu eğitim anlamında ilgilendiren konulara (müfredat, eğitimci, meslek edindirme, eğitim koşulları vb.) yer vermekte ve kapsamı gereği "herkes için olma” ilkesine göre 
hazırlanmaktadır. Bunun nedeni eğitimin temelde fırsat eşitliğine dayanması ve eğitim politikalarının da daha en başında bu adaleti sağlamakla yükümlü sayılmasıdır. Dolayısıyla eğitim politikaları, hitap ettiği kamu kitlesi olan çocuk ve gençlere ırk, cinsiyet, renk, dil, din ya da sağlık durumu ayırmaksızın hizmet eden bir noktada olmalı ve yukarıda sayılan özelliklerden özellikle 'fırsat eşitliği' ve 'birlik-bütünsellik" ilkesini tam olarak karşılayabilmelidir. Bu doğrultuda eğitim politikalarının toplumda özel gereksinimli olan ve olmayanlara benzer haklar tanıması ve hatta özel gereksinimli bireylere pozitif ayrımcılık yaparak buna uygun düzenlemeler geliştirmesi, uygulaması ve kamu açısından sorun olarak tanımlanan bir durumu eğitim boyutunda organize edip çözebilecek hedefleri, ilkeleri, yol ve yöntemleri belirleyerek çözüm, uygulama ve düzen noktasına getirmesi gerekmektedir. Eğitim politikalarının kapsamında bu süreci gerçekleştirebilmek için öncelikli olarak eğitimin altyapısının belirlenmesi, ekonomik durumun tespit edilmesi, ardından ise politik, yönetimsel ve mesleki gerekliliklerin sağlanması gerekmektedir (Y1lmaz, 2004, s. 26). Bunun sonrasinda ise;

-Özel gereksinimli bireylere dair farkındalık yaratılması,

-İhtiyaçların belirlenmesi ile birlikte çeşitli ön politikaların geliştirilmesi,

-Konu ile ilgili çalışacak olan kurulların (özel gereksinimli bireyler, politika geliştirme, özel eğitim vb. konularda uzman kişiler) oluşturulması gibi aşamalardan geçilmesi,

-Oluşturulan taslakların politika yapıcılara, siyasetçilere, savunuculara onaylatılmasının, farklı kurumlarla tartışılmasının, bunlar arasındaki eşgüdümün oluşturulmasının ve uygulama desteği alınmasının sağlanması,

-Son halinin verilmesinin ardından resmi olarak onaylatılması ve değerlendirilmesi (Montviloff, 1990, s. 22; Yılmaz, 2004, s. 26), yani eğitim politikası içinde özel gereksinimli bireylere dair bileşenler bulundurmak ya da konuya dair bir politika oluşturmak noktasında çeşitli aşamalardan geçilmesi sağlanmalıdır.

Eğitim politikaları ve özel bir konu olarak "özel gereksinimli olma” durumuna dair politikalar tüm ülkeler tarafından yukarıdaki aşamalardan geçilerek ulusal düzeyde hazırlanmakta ve aralarında yukarıdaki özellikleri taşıyan kapsayıcı iyi örneklerin bulunduğu görülmektedir. Bu iyi örneklere Avrupa Birliği (AB) ülkeleri arasında rastlandığı ve bu ülkelerin bu noktaya ulaşmalarında izledikleri yolları $\mathrm{AB}^{\prime}$ ye girmek isteyen ülkelere birer kriter paketi olarak sundukları görülmektedir.

Avrupa Birliği'ne üye ülkelerde özel gereksinimli bireylere sağlanan eğitim hizmetlerinin ülkeden ülkeye farklılık gösterdiği, ülkelerin özel gereksinimlilere dair kendi toplumsal ihtiyaç ve önceliklerine yönelik eğitim hizmetlerini, kendi belirlediği yaklaşımlarla yönettiği görülmektedir. İtalya, Fransa, Portekiz, İspanya ve İngiltere gibi ülkelerde özel gereksinimli çocukların büyük çoğunluğu için yasal olarak zorunlu tutulan kaynaştırma programları uygulanmakta; Almanya, Hollanda, Finlandiya gibi ülkelerde ise özel gereksinimli bireylerin ihtiyaçlarına özgü eğitim yapan özel okullara yönlendirildikleri görülmektedir. Bunun yanı sıra $\mathrm{AB}$ ülkelerinin neredeyse tamamında özel eğitim hizmetleri okul öncesi dönemden başlatılmakta, 'erken müdahale' kapsamında İngiltere, Danimarka, Avusturya gibi ülkelerde sistem doğumdan itibaren harekete geçmektedir. Çocukların gereksinimlerinin farkında olunması, buna uygun olarak mümkün olduğunca erken yaşta yönlendirilmesi noktasında sadece sorun çözücü değil, önleyici ve korumacı politikalar izleyen $A B$ ülkeleri bu nedenle daha uzun soluklu daha kapsayıcı ve yararlı olabilmektedir (T.C. Kalkınma Bakanlığı, 2015, s. 78).

Avrupa Birliğine üye olan ülkelerin eğitim politikaları incelendiğinde, özel gereksinimli bireylere eğitim konusunda "fırsat eşitliği" noktasına vurgu yaptıkları ve bu çocukların toplum içindeki yerlerini almalarını sağlamak için yaptıkları çalışmaları belirtilen noktadan harekete geçirdikleri söylenebilmektedir (Vural, Yücesoy ve Ünlü, 2003, s. 143-144). Türkiye'nin AB'ye giriş sürecinde AB tarafından hazırlanan yıllık ilerleme raporlarında ise; Türkiye'nin eğitim sisteminin genelde $A B$ eğitim politikalarıyla uyumlu olduğu; fakat eğitim hizmeti, dersler, eğitim personeli ve genel personel açısından AB standartlarının gerisinde olması, yoksul kesimdeki eğitim açığının büyük, eğitim imkânları ve yaşam boyu öğrenmeye katılımın düşük olması gibi eğitime erişim konusunda Türkiye ile $\mathrm{AB}$ arasında çarpıcı farklılıklar bulunduğu belirtilmiş; her yıl izlenen 
gelişmelerin sınırlı düzeyde olduğu vurgulanmıştır. Türkiye'de özel gereksinimli çocukların eğitimi ile ilgili politikalara önem verilmesi ve buna dair olarak $A B$ ülkelerinden yapılacak modellemelerle yol alınması, Türkiye'nin gelişmiş bir ülke olması ve $\mathrm{AB}^{\prime}$ ye giriş sürecinde olumlu bir adım sayılması anlamında önemlidir. Dolayısıyla ülkemizin gereken düzenlemeleri yapıp, kaynaklarını da doğru kullanarak ve fırsat eşitliği ilkesini ön planda tutarak özel gereksinimlilik kavramını çalışmayı hızlandırması gerekmektedir (Sağlam, Özüdoğru ve Çıray, 2011, s. 92, 105).

Eğitim bilgi çağının önemli bir parçası ve ülkelerin gelişmişlik düzeyleri için önemli bir göstergedir. Günümüz dünyasında eğitim tüm insanların eşit fırsatlarla yararlanması gereken bir insan hakkı olarak ele alınmaktadır. Eğitimin kalitesinin artırılması için bu noktadan harekete geçilerek yapılan çalışmalar eğitim politikalarını da şekillendirmiştir. Fırsat eşitliği konusunun ön plana alınmasına, eğitim politikalarının buna göre yazılıp uygulanmasına ve özel gereksinimli bireylerin de eğitim haklarından tam anlamı ile yararlanabilmesine vurgu yapılmıştır. Daha önce pasif, çaresiz, muhtaç, sakat olarak tanımlanan ve tedavi edilmesi gerektiği düşünülen özel gereksinimli bireyler sonrasında aktifleşerek hak arayışına girmiş ve hak temelli yaklaşımlar yoluyla kazanımlar elde etmişlerdir (Akçamete, Büyükkarakaya, Bayraklı ve Yıldırım, 2012, s. 194; Aktel ve Erten, 2017, s. 166; T.C. Aile, Çalışma ve Sosyal Politikalar Bakanlı̆̆ı, 2019, s. 2). Bu sürecin başlangıcını Birleşmiş Milletler oluşturmuş ve devamında çok sayıda düzenleme ve çalışma gerçekleştirilmiştir. Bunlar arasında;

-1975 yılında İnsan Hakları Evrensel Beyannamesi'ne ek olarak yayınlanan Engelli Hakları Bildirgesi,

-1993 yılında ilan edilen Engelliler İçin Fırsat Eşitliği Konusunda Standart Kurallar ve

-2006 tarihli Engelli Haklarına İlişkin Sözleşme bulunmaktadır (Aktel ve Erten, 2017, s. 167-168).

Özel gereksinimlilere ilişkin olarak oluşturulan her bir politikanın eğitim içeriği de bulunmakta ve bu sayede uluslararası platformlarda ciddi çalışmalar yapılmaktadır. Sosyal modelin ${ }^{1}$ belirlenmesi ile birlikte 20 . yüzyılın son çeyreğinden itibaren genel eğitim sistemi içinde önemli değişiklikler ve düzenlemeler yapılmıştır. Özel gereksinimli çocukların fark edilmesi, performanslarının sağlanması, diğer çocuklardan ayrıştırılmadan eğitim alması, eğitimin parasız olması, en az kısıtlayıcı bir ortamda gerçekleştirilmesi, bireyselleştirilmiş eğitim programlarının hazırlanması, ayrım gözetmeden değerlendirme yapılması, ailelere katılımın, süreci izlemenin ve itiraz etme hakkının sağlanması gibi "kapsayıcı eğitim yaklaşımına giden bir süreç" izlenmiştir (Akçamete ve diğerleri, 2012, s. 195). Birleşmiş Milletler Çocuklara Yardım Fonu (United Nations International Children's Emergency Fund [UNICEF]) Türkiye 2019 yıllık raporunda, engeli olan çocukların haklarının korunması için özel çabalar gerektiği vurgulanmakta, bu çocukların hizmetlere ulaşım ihtiyaçlarının karşılanmasının önemine değinilmektedir. 2018 Türkiye Nüfus ve Sağlık Araştırmasının sonuçlarından elde edilen verilerle, özel gereksinimleri olan çocukların erken tespit ve sınıflandırılmasının iyileştirilmesine, onlara mümkün olan en erken yaştan itibaren uygun destek/hizmet sağlanmasına yönelik hazırlanan "Çocuklar için Özel Gereksinim Raporu" nun hem Sağlık Bakanlığı, hem de Aile, Çalışma ve Sosyal Hizmetler Bakanlığı tarafından onaylandığı belirtilmektedir (UNICEF, 2019, s. 7). Birleşmiş Milletler Kalkınma Programı (United Nations Development Programme [UNDP]) kapsamındaki sürdürülebilir kalkınma hedeflerinin 4. ve 10. Maddelerinde de eğitim ve eşitsizliklerin azaltılmasına yer verilmekte ve özellikle tüm çocuklarla birlikte özel gereksinimlilerin de eğitim hakları için kaliteli veri, bilgi ve savunuculuk sunulmaktadır (UNDP Türkiye, 2020). Engeli olan çocuklarla birlikte tüm kız ve erkek çocuklarına erken çocukluktan ergenliğe kadar kapsayıc1, kaliteli eğitim sağlamak için kapasitesi geliştirilen eğitim sisteminden söz eden UNICEF (2019, s. 11), öğretmen ve yöneticiler için kapsayıcı eğitime yönelik eğitim programlarının geliştirilmesi konusunda ek modüller hazırlamış, Rehberlik ve Araştırma Merkezlerinin rehberlik sağlama etkisinin arttırılması için kamu bilgilendirmeleri düzenlemiş, engelli olan çocukların erken çocukluk eğitimine dâhil edilmesine yönelik kapsamlı eğitim materyalleri geliştirmiş ve sürdürülebilirliği de sağlamak amacıyla gençlik güçlendirme modüllerini uygulamaya almıştır. Birleşmiş Milletler Eğitim, Bilim ve Kültür Örgütü (United Nations

\footnotetext{
${ }^{1}$ Sosyal model özel gereksinimli olmayı bireysel, çevresel, hukuki, siyasi vb. birçok faktörün bir araya gelerek oluşturduğu bir deneyim olarak görmekte ve araştırma odağını engelli birey ve ailesinden uzaklaştırıp geniş toplumsal dünyaya yöneltmesi bakımından bilim disiplininden gelenler için değerli bulunmaktadır (Meşe, 2014, s. 88).
} 
Educational, Scientific and Cultural Organization [UNESCO]) Küresel Eğitim İzleme Raporu'nun (2020, s. 1) Türkiye analizinde ise Türkiye'de engelli olduğunu belirten 18-24 yaş arası gençlerin okuldan erken ayrılma oranının \%60'ın üzerinde seyrettiğine ve bu sonuçla Türkiye'nin Avrupa'da birinci olduğuna dikkat çekilmektedir. Türkiye'de de 1960'lı yıllardan itibaren başlayan çalışmalar; 1961 Anayasası'nda özel eğitime ilişkin maddelerin yer alması, 1985'te Özel Eğitim Yönetmeliği'nin çıkarılması ve devamındaki pek çok politika belgesi ile sürmüştür (Akçamete ve diğerleri, 2012, s. 197).

Eğitim politikalarını AB eğitim politikaları doğrultusunda değerlendiren çalışmalar; mevzuatta özel gereksinimli bireylere sağlanması gereken eğitim/özel eğitim hizmetlerine dair önemli gelişmeler kaydedildiğini, ancak hizmetlerin az sayıda kişiye ulaşmasından dolayı niteliğinin tartışmalı olduğunu (Cansever, 2009, s. 229; Vural ve diğerleri, 2003, s. 141), Avrupa Birliği'nde bedensel gereksinimler için sosyal politikalar geliştirildiğini, eğitim başlığı altında fırsat eşitliğine vurgu yapıldığını, Türkiye'de de temel eğitim programında özel eğitim ve sosyal yardımlar gibi boyutlarda eğitim yatırımları gerçekleştirildiğini (Terzi, 2005, s. 5, 50, 132), özel eğitim, özürlüler, engelliler ve ilgili kavramlara yeterince yer verilmediğini (Demir, 2015, s. 70; Sağlam ve diğerleri, 2011) ve AB sürecinde özel gereksinimli bireylere de ciddiyetle değinilmesi ve dikkate alınması gerektiğini (Bağcı, 2011, s. 156) vurgulamaktadır. Dünyada ve Türkiye'de özel gereksinimli bireylere yönelik kamu politikalarının gelişimi ile ilgili araştırmalarda; özel gereksinim olgusunun ulusal politikaların gündemine nasıl girdiği incelenmekte, kavramın tarihsel sürecinin ve ilgili politika belgeleri hakkında sosyolojik bakış açısı ile yapılan tespitlere yer verilmektedir. Gül, Cantürk ve Gül (2016, s. 785), 2007 tarihli Avrupa Birliği Sözleşmesi'nin Türkiye'ye özel gereksinimli bireylerin eğitimi ile ilgili hükümler getirdiğini, sosyal modele dayalı politikaların oluşturulduğunu ancak uygulamada ciddi sorunlar yaşandığını ifade etmektedir.

Hükümet programlarının ve siyasi partilerin eğitim politikalarının incelendiği çalışmalarda, siyasi partilerin farklı önceliklere sahip oldukları (Usta, 2015, s. 66), 1923'ten bu yana görev yapmış olan hükümetlerin sadece yirmi altısının programında özel gereksinimlilere yönelik amaç ve hedeflerden söz edildiği, öncelik sırlamasının ise sosyal yardımlar, sağlık ve rehabilitasyonun aldığı, eğitimin daha sonra geldiği (Aktel ve Erten, 2017, s. 175) görülmektedir. Politika belgelerinin tek tek ele alındığı ve eğitim politikası bileşenlerinin incelendiği bazı çalışmalarda ise Milli Eğitim Şuralarında "özel gereksinimli olma" konusuna özel bir başlık ayrılmadığı, bazılarında konuya 'öğrenci rehberlik hizmetleri' kapsamında, bazılarında ise 'diğer konular' alt başlığı altında özel eğitim içeriğiyle değinildiği (Kılıç ve Güven, 2017, s. 593-595), 1961 ve 2005 yılları arasını inceleyen araştırmacıların (Eriş, 2006, s. 190; Üçler, 2006, s. 50, 68) yaptıkları çalışmalarda da Milli Eğitim Şuraları hakkında benzer yorumlarda bulundukları izlenmektedir. Durmuş $(2018$, s. 445) ise Şuraların, yapıldığı dönemlerde eğitim politikalarının tüm içerikleri üzerinde durduğunu, özellikle özel yetenekli çocukların eğitiminin önemli işlevlerinden biri olan rehberlik hizmetleri ve eğitim sistemindeki uygulamalar üzerinde çalışıldığını (8. Milli Eğitim Şurası'ndan itibaren) belirtmiştir.

İncelenen çalışmaların bazıları özel gereksinimli bireylerin haklarının tanımlanması ve kazanılması (Akçamete ve diğerleri, 2012; Aktel ve Erten, 2017; T.C. Aile, Çalışma ve Sosyal Politikalar Bakanlığı, 2019) üzerinde durmuştur. Bazı çalışmalar (Akçamete ve diğerleri, 2012) özel gereksinimli çocukların eğitimlerinin içeriğine vurgu yapmıştır. AB eğitim politikalarından yola çıkan bazı araştırmalar (Bağc1, 2011; Cansever, 2009; Demir, 2015; Gül ve diğerleri, 2016; Sağlam ve diğerleri, 2011; Terzi, 2005; Vural ve diğerleri, 2003) ise özel gereksinimli bireylerin eğitim hizmetlerinin niteliği ve niceliğini tartışışlardır. Politika belgelerinin ele alındığı bazı çalışmalarda ise kavramın bir alt başlık olarak ele alınmasına değinildiği (Eriş, 2006; Kılıç ve Güven, 2017; Üçler, 2006) görülmüştür.

Araştırmanın problemi, “Türkiye'de halen yürürlükte olan ilk ve orta öğretim düzeyindeki eğitim politikalarında özel gereksinimliliğe ilişkin yaklaşım nasıldır?" biçiminde oluşturulmuştur. Çalışmada aynı zamanda aşağıdaki araştırma sorularına yanıt aranacaktır:

1. Türkiye'de halen yürürlükte olan ilk ve orta öğretim düzeyindeki eğitim politikası belgelerinde özel gereksinimli olma kavramına ne kadar yer verilmektedir? 
2. Türkiye'de halen yürürlükte olan ilk ve orta öğretim düzeyindeki eğitim politikası belgelerinde özel gereksinimli olma kavramı hangi açılardan ele alınmaktadır?

3. Türkiye'de halen yürürlükte olan ilk ve orta öğretim düzeyindeki eğitim politikası belgelerinde özel gereksinimli olma kavramına ilişkin yaklaşım uygulanabilir ve sürdürülebilir nitelikte midir?

\section{Yöntem}

İçerik analizi yöntemiyle gerçekleştirilen bu çalışmanın amacı, Türkiye' de halen yürürlükte olan ilk ve orta öğretim düzeyindeki eğitim politikasının özel gereksinimli bireylere ilişkin yaklaşımlarını ortaya koymak ve değerlendirmektir. Çalışmada politika belgeleri içerik analizi yöntemiyle tek tek incelenerek "özel gereksinim", "engellilik", “özürlü olmak", "özel eğitim gerektiren birey” gibi kavramların geçtiği bölümler değerlendirilmiştir. Bu kavramlara yer verilip verilmediği, hangi açılardan ele alındığı ve uygulamaya dönük özellikleri yorumlanmış ve genel bir bakış açısı oluşturulmaya çalışılmıştır. Bu kapsamda, Türkiye'deki yasal belgeler yani dokümanlar analiz edilmiştir. Doküman incelemesi araştırılması hedeflenen olgu ve olaylar hakkında bilgi içeren yazılı materyallerin analizi iken, içerik analizinde yapılan işlem, birbirine benzeyen veriyi belirli kavramlar ve kategoriler çerçevesinde bir araya getirmek ve bunları okuyucunun anlayabileceği şekilde düzenleyerek yorumlamaktır (Yıldırım ve Şimşek, 2011, s. 187, 227). Bu amaca bağlı olarak araştırmanın kapsamını da Türkiye' de özel gereksinimli bireylerle ilgili herhangi bir düzeyde içeriğe ve dolayısıyla ilgililiğe sahip ve halen yürürlükte olan eğitim politikası belgelerinin incelenmesi oluşturmaktadır. Bu kapsamda incelenecek eğitim politikası belgeleri:

-Türkiye Cumhuriyeti 1982 Anayasası,

-Milli Eğitim Bakanlığı 2019-2023 Strateji Planı,

-222 sayılı Türkiye Cumhuriyeti Milli Eğitim Bakanlığı İlköğretim ve Eğitim Kanunu,

-29072 sayılı Milli Eğitim Bakanlığı Okul Öncesi Eğitim ve İlköğretim Kurumları Yönetmeliği,

-1739 sayılı Milli Eğitim Temel Kanunu,

-5378 sayılı Engelliler Hakkında Kanun,

-5580 sayılı Özel Eğitim Kurumları Kanunu,

-652 sayılı Milli Eğitim Bakanlığının Teşkilat ve Görevleri Hakkında Kanun Hükmünde Kararname,

-573 sayılı Özel Eğitim Hakkında Kanun Hükmünde Kararname,

-30471 sayılı Özel Eğitim Hizmetleri Yönetmeliği,

-4.-11. Kalkınma Planları,

-8.-12. ve 17-19. Milli Eğitim Şuraları, Özürlüler Şurası,

-Uluslararası Katılımlı Engelsiz Bilişim 2013 Sempozyumu kapsamında FATİH Projesi ve Engelliler Çalıştayı,

\section{-3. Eğitim Teknolojileri Zirvesi olarak sıralanabilir.}

Hem genel anlamda, hem de özel anlamdaki hukuki hiyerarşi; anayasa, yasalar, yasa hükmündeki kararnameler, yönetmelikler ve yönergeler biçiminde oluşmaktadır. Anayasa en genel, kanun o genel çerçeveyi detaylandıran, yönetmelik o uygulamaları yazan ve yönergeler de teknik anlamda kılavuzluk yapan hukuksal belgelerdir. Bu belgelerden Anayasa ve Kalkınma Planları, her konuda temel kabul edilen politika belgeleri oldukları için; Strateji Planları kanunları çerçevelediği ve ilgili kanunların çıkışına zemin hazırladıkları için; kanun ve kararnameler, eğitim alanındaki temel eğitim politika belgeler ve ana kanunlar oldukları için ele alınmıştır. Yönetmelikler, özel eğitim gereksinimi olan bireylere özgü olarak çıkarılmış yönetmelikler olduğu için; sivil toplumu da konunun içine dâhil ettikleri için ele alınan şuralar çalıştaylar ise özel gereksinimli bireylerin ele alındıkları arasından seçilmiştir. 


\section{Bulgular ve Tartışma}

Bu bölümde, Türkiye'de halen yürürlükte olan ilk ve orta öğretim düzeyindeki eğitim politikasında özel gereksinimli olmaya ilişkin yaklaşım ile ilgili politika belgeleri üzerinden elde edilen bulgular sunulmuştur. Türkiye'de genel anlamda bakıldığında eğitim sistemine yön veren/belirleyici olan politik/hukuki belgelerin 1982 Anayasası, 1739 sayılı Milli Eğitim Temel Kanunu, 222 sayılı İlköğretim ve Eğitim Kanunu, 652 sayılı Milli Eğitim Bakanlığı Teşkilat ve Görevleri Hakkındaki Kanun Hükmünde Kararname ve 2547 sayılı Yükseköğretim Kanunu olduğu söylenebilir. Türk Eğitim Politikasında “özel gereksinimli olma" kavramını ele alan ilgili politika başlıklarına aşağıda yer verilmiş ve bu kavrama ilişkin içerikleri açısından incelenmiştir.

\section{T.C. 1982 Anayasas1}

Devletin temel yapısını, yönetim biçimini, devlet organlarının birbirleriyle olan ilişkilerini, kişilerin temel hak ve özgürlüklerini düzenleyen, kısaca, bir ülkenin toplumsal, ekonomik ve siyasal düzenini biçimlendiren temel yasa ve politika belgesi olan Anayasa, aynı zamanda tüm yasal belgelerin ve politikaların kaynağı olarak kabul edilmektedir (Yılmaz, 2004, s. 104). Halen yürürlükte olan 1982 Anayasasına (Türkiye Cumhuriyeti, 1982) bakıldığında eğitim kapsamında özel gereksinim kavramına yer veren maddelerin 10. Madde, 42. Madde ve 61. Madde olduğu görülmektedir. 1982 Türkiye Cumhuriyeti Anayasasi'nda, Türkiye'deki eğitim politikasındaki özel gereksinimli olma kavramına doğrudan ya da dolaylı değinen bu maddeler şöyle değerlendirilebilir:

Anayasanın 10. Maddesi "Kanun Önünde Eşitlik" başlığı altında, öncelikle kanun önünde herkesin ayrım gösterilmeden eşit olduğuna ve eşit haklara sahip olduğuna değinmektedir. 'Herkes' sözünün açılımı yapılırken, çocuklar, yaşlılar, harp ve vazife şehitlerinin dul ve yetimleri, malul ve gazilerin yanı sıra "özürlülerden" de söz edildiği görülmektedir. Bu durum devlet organları ve idare makamlarının uygulayacağı eğitim politikalarını da içine alan tüm işlemlerde geçerli sayılmaktadır. Özel gereksinimli gruplara herhangi bir ayrıcalık sağlamamakla birlikte, bu gruba dair alınacak tedbirlerin, eşitlik ilkesine aykırı sayılamayacağına da vurgu yapılmaktadır. Bu noktada dolaylı olarak özel gereksinimli bireyler için pozitif ayrımcilık taşıyan haklardan söz etmek de mümkündür.

Madde 42'de 'herkes' sözünden 'kimse' içeriğine geçilmiş ve öğrenim hakkı konusunda kimsenin eğitim ve öğrenimden yoksul bırakılamayacağı belirtilmiştir. İlköğretim eğitiminin kız ve erkek tüm vatandaşlar için zorunlu ve ücretsiz olduğuna dair yapılan vurgu özel gereksinimli çocukları da kapsamaktadır. Ancak imkân yoksunluğu ile ilgili kısımda sadece maddi imkânların ele alınmış olması; başarının kritik edilmesi ve maddi imkânlardan yoksun olan başarılı öğrencilere öğrenimlerini sürdürebilmeleri için burslar ve başka yollarla gerekli yardımların yapılması durumu kapsayıcı görünmemektedir. Verilen eğitim hizmetlerine mülteci/göç mağduru olan, ihmal ve istismara uğrayan, coğrafi nedenlerden/üstün yetenekli olmasından/özel gereksiniminden dolayı erişim sorunu yaşayan tüm çocuk vatandaşların bu kapsama alınarak ifadelendirilmesi gerekmektedir. Bu haliyle Anayasa'nın 42. Maddesi eğitime destek konusunda sadece fakirlik ve başarılı olmak noktasında bir içerik sunmakla kalmış, farklı durumlar dışında özel gereksinimli çocukları da dışarıda bırakmış gözükmektedir. İlerleyen alt maddelerde "Devlet, durumları sebebiyle özel eğitime ihtiyacı olanları topluma yararlı kılacak tedbirleri alır" (Madde 42, 9/2/2008 tarihli ek fıkra) ifadesi ile bu kapsayıcılık verilmeye çalışılmış, ama "öğrenimlerini sürdürerek" yerine "topluma yararlı hale gelmek" noktasında özel gereksinimli çocuklar için muhtaç, eksik, topluma kazandırılması gereken anlamlarını taşıma olasılığı olan yani yorum içeren ifadelere yer verilmiştir. Bu noktada madde ifadelerinin farklılıklara sayg1 bakımından desteklenmesi ve düzenlenmesi, özel gereksinimli bireylerin anayasadaki tanımlamalarını ve dolayısıyla toplumdaki eğitim, hukuk, sosyal yaşamlarına dair yansımalarını da olumlu anlamda değiştirecektir.

Madde 61'de ise "Sosyal Güvenlik Bakımından Özel Olarak Korunması Gerekenler" başlığı altında özel gereksinimli bireylerin korunmalarını, toplum hayatına uyumlarını sağlayan tedbirlerden ve buna dair uygun teşkilat ve tesislerin kurulacağından (okul, eğitim kurumu gibi) söz edilmektedir. Daha çok koruma ve kazandırma noktasına vurgu yapıldığı görülmektedir. 
Sözü edilen maddeler 1982 Anayasası'nda geçen ve özel gereksinimli bireylerin eğitim politikaları bakımından ele alınabilecek olan maddelerdir. Genel olarak yapılması gereken ilk değerlendirme kavram kargaşasına yöneliktir. Anayasa maddelerinde "özel gereksinim" kavramı geçmemekte, onun karşılığı olabilecek bir kavrama da yer verilmemektedir. "Özürlü", "özel eğitime ihtiyacı olan", "sakat" ve "korunmaya muhtaç çocuk "gibi pek çok ifadenin kullanıldığı (Özürlü-Madde 10, Özel Eğitime İhtiyacı Olan-Madde 42, 9/2/2008 tarihli ek fikra, Sakat-Madde 61, Korunmaya Muhtaç-Madde 61), tüm gereksinim gruplarının adının geçirilemediği görülmektedir. Sayılan özel durumların hepsini kapsamına alacak özel gereksinim gibi tek bir çatı kavramın da kullanılmamasından dolayı bazı gereksinim gruplarına dair tanımlama ve farkındalıkların yetersiz kalabileceği düşünülmektedir. Diğer yandan, maddeler kendi içlerinde incelediklerinde ise özel gereksinimli bireylerin eğitimi ile ilgili olabilecek içeriklerde eşitlik ilkesine/haklara (Madde 10, 7/5/2004 ve 12/9/2010 tarihli ek fikralar), korumaya ve yardıma (Madde 61), kaynak ve ortam oluşturmaya (Madde 42, 9/2/2008 tarihli ek fıkra) vurgu yapılmasının sevindirici olduğu, ancak kullanılan terimlerin aynı zamanda bu bireyleri zayıf ve güçsüz gösterdiği çıkarımı yapılmıştır. Kısaca, 1982 Anayasası'nın, özel gereksinimli olma kavramı için, eğitim politikası bağlamında beklenen dayanağı sağladığı, ancak ilgili maddelerin ifadelerinde (Madde 10, Madde 42 ve Madde 61'de geçen ve yukarıda aktarılan ifadeler) daha kapsayıcı ve bütünleştirici olabileceği söylenebilir.

\section{Eğitim Yasaları (Kanunlar)}

Yasalar bir ülkede anayasadan sonra en bağlayıcı hukuksal metinlerdir. Bu nedenle ülkedeki politik algılayışı ve eğilimi yansıtmaktadırlar (Yılmaz, 2004, s. 111). Dolayısıyla özel gereksinimli olma gibi bir kavramın eğitim ile ilgili yasaların kapsamında nasıl ele alındığının incelenmesi gerekmektedir. Bu noktada halen yürürlükte olan ve kavrama dair içerikler barındıran aşağıdaki yasalar incelenmiştir:

1961 yılında yürürlüğe giren 222 sayılı İlköğretim ve Eğitim Kanunu'na bakıldığında Madde 12'de belirtilen "Mecburi ilköğretim çağında bulundukları halde zihnen, bedenen, ruhen ve sosyal bakımdan engelli olan çocukların özel eğitim ve öğrenim görmeleri sağlanır" ifadelerinde özel gereksinimlilik kavramına değinildiği görülmektedir (T.C. Milli Eğitim Bakanlığı, 2010a; T. C. Milli Eğitim Bakanlığı İlköğretim ve Eğitim Kanunu, 2020).

1739 sayıl Milli Eğitim Temel Kanunu'nda bakıldığında; söz konusu kanunun “Türk milli eğitiminin düzenlenmesinde esas olan amaç ve ilkeler, eğitim sisteminin genel yapısı, öğretmenlik mesleği, okul bina ve tesisleri, eğitim araç ve gereçleri ve devletin eğitim ve öğretim alanındaki görev ve sorumluluğu ile ilgili temel hükümleri" içerdiği görülmektedir. İlgili kanunun 4. Maddesinde "Eğitim Kurumları dil, ırk, cinsiyet, engellilik ve din ayrımı gözetmeksizin herkese açıktır" ifadesi ile "genellik ve eşitlik" üzerinde durulmakta; Madde 8'de ise "Eğitimde kadın/erkek herkese fırsat ve imkân eşitliği sağlanır" denmekte ve "Özel eğitime ve korunmaya muhtaç çocukları yetiştirmek için özel önlemler alınır" ifadesi ile özel gereksinimli olma kavramına değinilmektedir (Milli Eğitim Temel Kanunu, 1973).

5378 sayılı Engelliler Hakkında Kanununun, özel gereksinimli olma kavramını özürlülük ve engellilik olarak tanımladığı görülmektedir. Kanun, Başbakanlık Özürlüler İdaresi Başkanlığınca özürlülük alanında çağdaş dünyadaki gelişmeler ve evrensel ilkeler ışığında, özürlülerin sorunlarının çözümü için yeni ve sosyal politikalara ve özürlüleri ilgilendiren mevzuatın yeniden düzenlenmesine duyulan ihtiyaçtan hareketle 2005 yılında yürürlüğe girmiştir. Kanun; özürlüleri, ailelerini, özürlülere yönelik hizmet veren kurum ve kuruluşlar ile diğer ilgilileri kapsamaktadır (T.C. Milli Eğitim Bakanlığı, 2010a). Kanunun ilk maddesinde amaç, "engellilerin temel hak ve özgürlüklerden faydalanmasını teşvik ve temin ederek ve doğuştan sahip oldukları onura saygıyı güçlendirerek toplumsal hayata diğer bireylerle eşit koşullarda tam ve etkin katılımlarının sağlanması ve engelliliği önleyici tedbirlerin alınması için gerekli düzenlemelerin yapılmasını sağlamak" olarak açıklanmaktadır (T.C. Milli Eğitim Bakanlığı, 2005). Diğer bir deyişle kanunun amacı; özürlülügüun önlenmesi, özürlülerin sağlık, eğitim, rehabilitasyon, istihdam, bakım ve sosyal güvenliğine ilişkin sorunlarının çözümü ile her bakımdan gelişmelerini ve önlerindeki engelleri kaldırmayı sağlayacak tedbirleri alarak topluma katılımlarını sağlamak ve bu hizmetlerin koordinasyonu için gerekli düzenlemeleri yapmak şeklinde özetlenebilmektedir (T.C. Milli Eğitim Bakanlığı, 2010a). 
5580 sayılı Özel Öğretim Kurumları Kanunu 2007 yılında yürürlüğe alınmıştır. Kanunun 2. Maddesinin h) bendine göre "Özel eğitim okulu: Özel eğitim gerektiren bireylere hizmet veren, özel olarak yetiştirilmiş personelin bulunduğu, geliştirilmiş eğitim programlarının uygulandığı özel öğretim kurumu." k) bendine göre "Özel eğitim ve rehabilitasyon merkezi: Özel eğitim gerektiren bireylerin konuşma ve dil gelişim güçlüğü, ses bozuklukları, zihinsel, fiziksel, duyusal, sosyal, duygusal veya davranış problemlerini ortadan kaldırmak ya da etkilerini en az seviyeye indirmek, yeteneklerini yeniden en üst seviyeye çıkarmak, temel öz bakım becerilerini ve bağımsız yaşam becerilerini geliştirmek ve topluma uyumlarını sağlamak amacıyla faaliyet gösteren özel öğretim kurumları" olarak tanımlanmış ve böylelikle sınırları belirlenmiştir (T.C. Milli Eğitim Bakanlığı, 2010a).

Eğitim ile ilgili yasaların bir ülkenin eğitim politikasını büyük ölçüde ortaya koyduğu düşünüldüğünde, özel gereksinimli olma gibi bir kavramın yasalara ne ölçüde yansıdığının incelenmesi son derece önemlidir. Bu amaçla; 222 sayılı İlköğretim ve Ĕ̆itim Kanunu, 1739 sayılı Milli Eğitim Kanunu, 5378 sayılı Engelliler Hakkında Kanun ve 5580 sayılı Özel Eğitim Kurumları Kanununun, bu kavramı eğitim politikaları kapsamında doğrudan ya da dolaylı hangi açılardan ele aldığı incelenmiştir. Resmi Gazete'de 1961 yılında yayınlanan ve hala yürürlükte olan 222 sayılı İlköğretim ve Eğitim Kanunu 91 maddeden oluşmaktadır. Genel anlamda ilköğretimin zorunlu ve ücretsiz olduğuna ve devlet okullarında zorunlu ilköğretim yaşının 6-13 olduğuna değinen Kanun içinde ilköğretim düzeyine gelen özel gereksinimli çocuklar ile ilgili tek bir madde barındırmaktadır. Madde 12 'de özel gereksinim kavramına engel ifadesiyle değinilmekte ve kapsamı zihinsel, bedensel, ruhsal ve sosyal olmak üzere bölümlere ayrılarak yeterli biçimde belirtilmekte, bu çocuklara 'yardım ya da para aktarımından' değil, 'özel eğitim ve öğrenim gerekliliğinden' söz edilmektedir. Önemli gerekliliklere vurgu yapan bu maddeye ek olarak, eğitim ve öğrenimin nasıl uygulanacağına dair de bilgilendirmede bulunulmasının durumu tamamlayacağı düşünülmektedir. Çünkü Madde 12 durumu tanımlamakta, kapsamın sınırını çizmekte, çözümü sunmakta, ancak bu çözümün nasıl uygulanacağına dair bir uygulama bilgisi sunmamaktadır. Bu nedenle eğitim politikasının en önemli gereklerinden biri olan yol/yöntem sunma aşamasını gerçekleştirilememektedir.

1973 yılında kabul edilen 1739 sayıl Milli Ĕ̆itim Temel Kanunu ise 64 maddeden oluşmakta ve özel gereksinimli olma kavramı ile ilgili olan maddelerin 4. ve 8. maddeler olduğu görülmektedir. Bu kanunun pek çok bileşeni içeren, son derece kapsamlı hazırlanmış, amaçlar/öğretim elemanı/sistemin yapısı/ eğitim ortamı/ eğitim materyali/ temel sorumluluklar noktasındaki detaylı açıklamalardan oluşan bir yapı sunduğu görülmektedir. Genellik ve eşitlik üzerinde durduğu Madde 4'de özel gereksinimli olma kavramına doğrudan yer vermediği, "herkese açıktır” ifadesinin kapsamına doğal olarak özel gereksinimli bireylerin de girdiği ve bu yönüyle 1982 Anayasası'nın 10. Maddesi ile benzer işleve sahip olduğu görülmektedir. Madde 8'de ise fırsat ve imkân eşitliğine vurgu yapılmasının ardından özel eğitime ve korunmaya muhtaç çocuklara değinildiği ve bu çocukların "eğitilmesi" için değil, "yetiştirilmesi" için tedbir alınmasına önem verildiği görülmektedir. Bu noktada 4. maddenin genellikle eşitlik ilkesine yer vermesinin önemli bir nokta olduğu, ancak "özel gereksinim" kavramını açıklamak, kapsamını çizmek, anlama dair bileşenleri belirtmek için tek bir maddenin ayrılmasının bu duruma dair hangi eğitim politikalarının, stratejilerinin uygulandığına dair yeterli bir yanıt veremediği, üstelik kısıtlı açıklama dâhilinde "eğitimden" değil, "yetiştirmekten" söz etmekle kaldığ1 söylenebilir. Aynı kanunun içinde, özel gereksinimli çocuklar için özel olarak hazırlanmış kanun niteliğinde başka bir politika evrakına gönderme yapılmadığının görülmesi, bu önemli kavramın havada kaldığını düşündürmektedir.

5378 sayılı Engelliler Hakkında Kanun 2005 yılında yürürlüğe girmiştir. 52 maddeden oluşan kanunun ana konusu, içeriği ve kapsamı tamamen özel gereksinimli bireylere dair düzenlemelere ayrılmıştır. Kapsamı; özel gereksinimliler, aileleri ve onlara hizmet veren kurum ve kuruluşları içermektedir. Kanunun ilk maddesinde "onura saygı" dan söz edilerek özel gereksinimli olma kavramı zayıf/muhtaç/hasta/zavallı/korunmaya muhtaç/sakat anlamlarından çıkarılmış; hedef güçlendirmek, toplumsal hayata etkin katılım sağlamak, önleyici tedbirler almak konusunda gerekli düzenlemeleri yapmak olarak belirlenmiştir. Bu kanun kapsamında özürlü-engelli kavramlarının birbirinin yerine sık kullanılmasından dolayı kavram kargaşası olduğu söylenebilir. Ancak içerik olarak önleme, erken müdahale, tanı, tedavi, bakım, güvenlik, istihdam, 
topluma katılım ve eğitim gibi önemli bileşenlere değinildiği ve gerekli düzenlemeleri (eğitimciler, mekân, araç-gereçler gibi) yapmak konusunda önemli bileşenleri içerdiği dikkat çekmektedir.

2007 yılında yürürlüğe giren 5580 sayılı Özel Eğitim Kanunu ise 16 maddeden oluşmaktadır. Bu kanunun 2. maddesi kapsamında özel gereksinimlilik kavramına "özel eğitim gerektiren bireyler" adı altında yer verildiği, ama ilgili bileşenlerin (özel bireyler, özel yetiştirilmiş personel, özel eğitim programları, özel eğitim kurumu) detaylarına tam olarak değinildiği görülmektedir. Ayrıca özel eğitim ile ilgili tüm alt başlıklar iyi derecede detaylandırılmış; tanılama, tedavi, sorunu aza indirme, yeteneği en üst düzeye çıkarma, bağımsız yaşam becerisi geliştirme gibi tanımlamalarla uygulamaya değinerek yol gösterebilen bir politika evrakı olarak değerlendirilebilmektedir.

Daha önce de vurgulandığı üzere, bir ülkede anayasadan sonra gelen en güçlü politika belgeleri olan yasalar, kamuyu ilgilendiren bir konuda bakış açısı, tanım ve uygulama sunmaktadır. Bir kavramın ne kadar iyi tanımlandığı, kapsamının ne derece sunulduğu, çözümlerin nasıl ortaya konulduğu ve yol ve yöntemlerin ne kadar uygulanabilir olduğu o yasanın ne kadar yeterli olduğunu da göstermektedir. Bu bağlamda, incelenen yasa maddelerinin özel gereksinimli olma kavramının sınırlarını çizmek konusunda eksik kaldığı, eğitim politikalarına dair hangi stratejilerin izleneceği konusunda ise yerinde vurgulamalar yapan, ama uygulanabilir olmayan içerikler sunduğu söylenebilir.

\section{Kararnameler}

Kanun Hükmünde Kararname (KHK) genel olarak; yasama organının konu, süre ve amacı belirleyen bir yetki kanunu ile verdiği yetkiye veya doğrudan doğruya anayasadan aldığı yetkiye dayanarak, hükûmetin çıkardığı, maddi anlamda kanun gücüne sahip, parlamentonun tasdiki ile şekli ve organik anlamda kanun gücünü kazanacak olan politika belgeleri olarak tanımlanabilir (Kanun Hükmünde Kararname, 2020). Türkiye eğitim politikasında özel gereksinimli olma kavramına yer veren KHK'ler şöyledir:

652 sayılı Kanun Hükmünde Kararname Milli Eğitim Bakanlığının görevleri ifade etmekte ve bu kapsamda;

-Madde 2'de kız öğrencilerin, özürlülerin ve toplumun özel ilgi bekleyen diğer kesimlerinin eğitime katılımını yaygınlaştırarak politika ve stratejiler geliştirmek, uygulamak ve uygulanmasını koordine etmek,

-Madde 43'de “Özürlü sağlık kurulu raporu düzenlemeye yetkili sağlık kurum veya kuruluşlarınca verilen sağlık kurulu raporuyla asgari \%20 oranında özürlü olduğu tespit edilen ve özel eğitim değerlendirme kurulları tarafından da eğitsel değerlendirme ve tanılamaları yapılarak 5580 sayılı Özel Öğretim Kurumları Kanunu kapsamında açılan özel eğitim okulları ile özel eğitim ve rehabilitasyon merkezlerinde verilen destek eğitimi almaları uygun görülen görme, işitme, dil-konuşma, spastik, zihinsel, ortopedik veya ruhsal özürlü bireylerin eğitim giderlerinin her yıl Maliye Bakanlığınca belirlenen tutarı, Bakanlık bütçesine bu amaçla konulan ödenekten karşılanır. Bu özürlü bireylerin özür grupları ve dereceleri ile özür niteliğine göre eğitim programlarının kapsamı ve eğitim süreleri, Aile ve Sosyal Politikalar Bakanlığının görüşü alınmak suretiyle yönetmelikle belirlenir" şeklinde özel gereksinimli bireyler ile ilgili açıklamalar yapılmaktadır (Millî Eğitim Bakanlığının Teşkilat ve Görevleri, 2011).

573 sayılı Özel Ĕ̆itim Hakkında Kanun Hükmünde Kararname ise özel eğitim gerektiren bireylerin Türk milli eğitiminin genel amaç ve temel ilkeleri doğrultusunda genel ve mesleki eğitim görme haklarını kullanabilmelerini sağlamaya yönelik esasları düzenlemek amacıyla hazırlanmıştır. Kapsamında Madde 3' ün altında engelli birey kavramı, özel eğitim gerektiren birey olarak tanımlanmakta, onların özür ve özelliklerine uygun ortamlarda, uygun personel ve yöntemlerle gerçekleştirilen eğitimin "özel eğitim" olduğu vurgulanmakta, bu bireylerin diğer bireylerle etkileşim içinde eğitim ortamlarında bulunması "kaynaştırma" olarak tanımlanmakta ve değerlendirme süreçleri de "tanılama" olarak aktarılmaktadır. Bu noktada kararnamenin maddeleri boyunca; özel eğitimin temel ilkelerinden (Madde 4), özel gereksinimli bireylere özel hazırlık sinıflarından (Madde 8), ilkokul ve ortaokul öğretmenlerinin özel eğitim okullarında ve/veya İlköğretim okullarında, genel ve mesleki teknik ortaöğretim okullarında eğitimi sürdürebileceklerinden (Madde 8 ve Madde 9), kaynaştırma (Madde 12) ve özel eğitim okullarında (Madde 13) eğitim alabileceklerinden, eğitim yaşantıları boyunca bireysel veya grupla eğitim imkânına sahip olacaklarından ve 
ihtiyaçlarına göre hazırlanmış bireyselleştirilmiş eğitim programları alabileceklerinden (Madde 14 ve Madde 15), değerlendirmelerinin özür ve özelliklerine göre yapılacağından (Madde 16), ihtiyaç duydukları noktada Rehberlik Araştırma Merkezlerinden (RAM) hizmet alabileceklerinden (Madde 17), eğer durumları ayrı bir okulu gerektiriyorsa özür ve özelliklerine uygun gündüzlü/yatılı özel eğitim okullarına gidebileceklerinden (Madde 18), durumu örgün eğitime devam etmesine uygun olan çocuklar için özel eğitim desteği sağlamak üzere yardımcı derslikler oluşturabileceğinden, özel materyallerin sağlanabileceğinden ve özel tedbirlerin alınabileceğinden (Madde 20), bu konu ile ilgili RAM'ların (Madde 21) okullarda bulunan rehberlik ve psikolojik danışma hizmetleri servislerinin hizmet sunacağından (Madde 22) söz edilmektedir (Özel Eğitim Hizmetleri Hakkında Kanun Hükmünde Kararname, 1997).

Burada belirtilen Kanun Hükmünde Kararnameler genel anlamda incelendiğinde özel gereksinimlilik kavramının ele alınış biçimi kısaca şöyle değerlendirilebilir:

Milli Eğitim Bakanlı̆̆ının görevlerini aktaran 652 sayılı Kanun Hükmünde Kararnamenin 2. ve 43. maddelerinde özel gereksinimli olma kavramından özürlülük olarak söz edildiği görülmektedir. İkinci maddede özürlüler toplumun özel ilgi bekleyen kesimlerinden biri olarak tanımlanmakta, sözü geçen "özel ilgi" ise eğitime katılımın yaygınlaştırılması için politika ve stratejiler geliştirmek, bunları uygulamak ve uygulanmasını sağlamak olarak detaylandırılmaktadır. Aslında bu noktada, özel gereksinimli bireylerin eğitimi konulu politikalar geliştirilmesine ve bunların çerçevesinin bu bireylerin ihtiyaçlarından yola çıılarak belirlenmesine dair açıklamalar son derece yerinde ve anlamlı görülmektedir. Sözü edilen açıklamalar, kamuyu ilgilendiren bir sorunun farkında olunduğunun ve düzenlenmesi için istek duyulduğunun göstergesidir. Madde 43' de ise tanılama, eğitsel değerlendirme, tedavi-rehabilitasyon ve rapor düzenleme gibi önemli aşamalar ortaya konarak yapılacak düzenlemeler haritalandırılmış; ayrıca gereksinim gruplarının tanımları teker teker geçirilerek kapsamı belirlenmiştir. Eğitim giderlerinin hangi bütçeden ve nasıl karşılanacağı açıklanmış ve konuya dair başka bir kanuna (5580 sayılı Özel Öğretim Kurumları Kanunu) gönderme yapılarak ek açıklamalar arayanlar bilgilendirilmiştir.

573 sayılı Özel Eğitim Hakkında Kanun Hükmünde Kararnamenin (1997) pek çok maddesinde (3., 4., 8., 9., 12., 13., 14., 15., 16., 17., 18., 20., 21., 22.), özel gereksinimli bireylerin eğitimi ile ilgili olabilecek her türlü bileşenin tanımlanıp aktarıldığı, izlenebilecek yol ve yöntemlerin belirtildiği, bu doğrultuda hem kendi başına bir kanun olarak önerilebilecek nitelik taşıdığı, hem de nitelikli içeriğe sahip bir politika belgesi olma noktasında uygulanabilir, sürdürülebilir ve devamlılığı sağlanabilir özellikte olduğu görülmektedir.

\section{Yönetmelik ve Yönergeler}

Yönetmelikler, bir ülkede yasalarla yapılan genel düzenlemelerin ayrıntılandırılması ve bu anlamda yasalarda bırakılan/kalan boşlukların doldurulması amacıyla çıkarılan hukuk belgeleridir. Yönetmelikler ayrıca, yasanın bulunmadığı bir hukuksal dayanak oluşturma ve uygulamayı düzenleme işlevlerini de karşılamaktadır (Yılmaz, 2004, s. 122). Türkiye eğitim politikaları kapsamındaki yönetmeliklerin özel gereksinimli olma kavramına yer verme düzey ve nitelikleri aşağıda incelenmiştir.

29072 sayılı Millî Ĕ̆itim Bakanlığı Okul Öncesi Ĕ̆itim ve İlköğretim Kurumları Yönetmeliğı̆'nde (2014) yer alan 97 maddeden sekizinin, özel gereksinimli öğrencilerin eğitimine yönelik hazırlanmış olduğu görülmektedir. Buna göre kayıt zamanı ve yaşı ile ilgili açıklamalara yer veren Madde 11'in ilgili alt maddelerinde "Şehit, harp malûlü ve muharip gazi çocukları ile rehberlik araştırma merkezi raporu ile yönlendirilmesi yapılan özel eğitime ihtiyacı olan çocukların yeni kayıtları, durumlarını belgelendirmeleri şartıyla ulusal adres veri tabanındaki adreslerine bakılmaksızın istedikleri okula yapılır" ve "Rehberlik ve araştırma merkezlerinde oluşturulan Özel Eğitim Değerlendirme Kurulunca hazırlanan rapor doğrultusunda tam zamanlı kaynaştırma yoluyla okul öncesi eğitim kurumlarına yönlendirilen 36-66 aylık çocuklar bu kurumlara kaydedilir. Bu sınıfların mevcutları 10 çocuk bulunan sınıflarda iki, 20 çocuk bulunan sınıflarda ise bir çocuk olacak şekilde oluşturulur" ve "Özel eğitim değerlendirme kurulu raporu doğrultusunda, tam zamanlı kaynaştırma yoluyla eğitimlerini sürdüremeyecek durumda olan ağır düzeyde yetersizliği bulunanlar ile birden çok yetersizliği olan çocuklar, bu kurumlarda fiziki mekânın uygun olması ve özel eğitim öğretmeni istihdam edilmesi kaydıyla açılan özel eğitim sınıflarına kaydedilirler" denilmektedir. 
Devam/devamsızlık ile ilgili olan Madde 18'de, "Kayıtları yapılan çocukların kuruma günlük eğitimi aksatmayacak şekilde devam etmelerinin sağlanması esastır. Ancak özel eğitim gerektiren çocukların sosyal uyum ve gelişim özelliğine göre günlük devam sürelerinde esneklik sağlanır" ifadesine; ölçme ve değerlendirmeyi kapsayan Madde 20'de ise "Kaynaştırma yoluyla eğitimlerine devam eden öğrenciler için; Bireyselleştirilmiş Eğitim Programı Geliştirme Birimi tarafından bireyselleştirilmiş eğitim programı (BEP) hazırlanır ve bu öğrencilerin başarıları, bu programda yer alan amaçlara göre değerlendirilir" ifadesine yer verildiği görülmektedir. Sağlık durumuna göre ders özelliklerini anlatan Madde 24' de "Sağlık durumları veya bedensel engelleri nedeniyle uygulamalı derslere giremeyecek durumda olan öğrenciler, bu durumlarını sağlık kurum ve kuruluşlarından alacakları raporla belgelendirmek zorundadır. Bu durumdaki öğrenciler, rapor süresince bu derslerde raporda belirtilen faaliyetlerden sorumlu tutulmazlar. Dersin özelliğine ve katıldıkları etkinliklere göre değerlendirilerek gerekli yerlerde raporlu oldukları belirtilir" ifadesinin kullanıldığı; bir dersin puanı ile ilgili olan Madde 27'de ise "Her iki dönemde veya dönemin birinde uygulamalı herhangi bir derste sağlık durumları veya bedensel engelleri nedeniyle sağlık raporunda belirtilen faaliyetleri yapamayanların bu dersin öğretim programında yer alan temel becerilere yönelik faaliyetlere katılımları değerlendirilerek verilen dönem puanlarının aritmetik ortalaması, o dersin yılsonu puanı sayılır" ifadesinin geçtiği belirtilmektedir. Öğrenci başarısı ile ilgili olan Madde 31'de, "Kaynaştırma ve özel eğitim sınıflarında eğitimlerine devam eden öğrencilere başarısızlıklarından dolayı sınıf tekrarı yaptırılmaz. Ancak velinin yazılı talebi ve Bireyselleştirilmiş Eğitim Programı Geliştirme Biriminin kararı doğrultusunda, ilkokulda kaynaştırma öğrencilerine bir defaya mahsus olmak üzere sınıf tekrarı yaptırılabilir" ifadesine değinildiği; okul öncesi eğitim kurumlarında ücretin alınması ve bütçenin hazırlanması ile ilgili olan Madde 68 'de "Durumlarını belgelendirmeleri kaydıyla şehit, harp malûlü ve muharip gazi çocukları ile okul öğrenci kontenjanının 1/10'u oranındaki yoksul aile çocuklarından ücret alınmaz. Bu durumdaki çocuklardan engelli olanlara öncelik tanınır" ifadesine yer verildiği görülmektedir. Son olarak destek eğitim ortamları ile ilgili olan Madde 84 'de ise "Kaynaştırma öğrencileri ile özel yetenekli öğrenciler için okul öncesi eğitim ve ilköğretim kurumlarında özel eğitim desteği verilmesi amacıyla okulun fiziki imkânları doğrultusunda destek eğitim odası açılabilir. Destek eğitim odasındaki eğitim hizmetleri, ilgili mevzuat hükümleri doğrultusunda yürütülür. Destek eğitim odasının öğretim materyalleri ve donanım ihtiyaçları öğrencilerin ihtiyaç ve özellikleri dikkate alınarak sağlanır" ifadelerinin geçtiği izlenmektedir (Millî Eğitim Bakanlığı Okul Öncesi Eğitim, 2014).

30471 sayılı Özel Eğitim Hizmetleri Yönetmeliği'nde (2018) Türk Milli Eğitiminin genel amaçları ve temel ilkeleri doğrultusunda, "özel eğitim ihtiyacı olan bireylerin eğitim haklarından yararlanmalarını sağlamaya yönelik usul ve esasları düzenlemek" hedeflenmektedir. Özel eğitim ihtiyacı olan bireyler sözünün kapsamında; ağır düzeyde otizm/zihinsel engelli/bedensel engelli, çok ağır düzeyde zihinsel engelli, görme engelli, hafif düzeyde otizm/zihinsel engelli, işitme engelli, orta düzeyde otizm/zihinsel engelli ve özel eğitim ihtiyacı olan ve özel yetenekli bireyler bulunmaktadır. Bu yönetmelikte özel eğitim ihtiyacı olan tüm çocuklara Milli Eğitim Bakanlığı'nın özel eğitim temel ilkeleri doğrultusunda (bireysel farklılıkların gözetilmesi, ilgi/istek ve yeterliliklerin göz önünde bulundurulması, erken müdahale, izole edilmeden/kaynaştırma yöntemiyle ve toplumla entegrasyonu bozulmadan gerekli uyarlamaların yapılması, tüm kurum ve kuruluşların paydaş olması, bireysel eğitim programlarının geliştirilmesi, ailelerin aktif katılımının sağlanması, özel eğitim politikalarının geliştirilmesi ve bu aşamada üniversiteler ve Sivil Toplum Kuruluşları [STK] ile birlikte çalışılması) ve eğitimin her tür kademesinde kaynaştırma/bütünleştirmenin esas alınacağı belirtilmektedir. Aynı yönetmelikte gereken durumlarda özel sınıf ya da kurumların açılabileceği, örgün eğitim saatleri dışında tamamlayıcı eğitim faaliyetlerine gidilebileceği, öğrenimlerini (ilkokul-ortaokul) tamamlayamayanların kayıtlarının açık öğretim okullarına yapılacağı, örgün eğitimden yararlanamayanlara uzaktan eğitimin yapılacağı, merkezi sınavlarda gerekli tedbirlerin alınacağı, özel yetenekli olanlara ise destek verileceği belirtilmektedir.

Yönetmelikler değerlendirildiğinde özel gereksinimli olma kavramına yeterince yer verilmiş olduğu söylenebilmektedir. Yönetmeliklerin, uygulamaları düzenlemeyi ana hedef olarak aldığı ve yasaları tamamlayıcı yönü düşünüldüğünde bu, son derece olumlu bir durum olarak ele alınabilir. 
İncelenen yönetmeliklerden ilki, İlköğretim ve Ĕ̆itim Kanunu ile çıkarılması öngörülen Okul Öncesi Eğitim ve Illköğretim Kanunları Yönetmeliği' dir. Yönetmeliğin geniş kapsamlı olduğu, ancak "özel gereksinimli olma" kavramının; engelli, özel eğitime ihtiyacı olan çocuk, bedensel engelli, kaynaştırma sınıfı öğrencisi gibi farklı terimlerle ele alındığı ve bunun kavram kargaşasına yol açabileceği, ayrıca tüm gereksinim gruplarını içeren bütüncül kavramları içermemesi nedeniyle kapsayıcı olmadığı düşünülmektedir. Yine de özel gereksinimli çocukların eğitim süreci boyunca yaşayabilecekleri durumlara, spesifik bir açıklık getiren çözümler/yol/yöntemler sunduğu ve bu noktada çocukların ailelerinden de söz edildiği görülmektedir. Yönetmeliğin ilgili maddelerinin; özel gereksinimli çocukların okul kayıtlarına, gerektiğinde nasıl nakil edileceklerine, içinde olacakları sınıfın uygun mevcuduna, mekân özelliklerine, devam mecburiyetlerine, bireyselleştirilmiş eğitim programlarına, rapor olabilecekleri durumlara, nasıl değerlendirileceklerine, ücretlendirmelerine, çeşitli koşullardaki öncelik durumlarına ve destek eğitim haklarına detaylı olarak değinildiği izlenmektedir.

30471 sayıl Özel Eğitim Hizmetleri Yönetmeliği'nde ise özel eğitim gereksinimi olan öğrencilerin eğitim düzenlemelerinden söz edilmekte ve gerekli tüm detayların ele alındığı görülmektedir. Bu yönetmeliğin ayırıcı noktası; STK'lar gibi paydaşlardan, ailelerin eğitime dair ihtiyaçlarından, çocukların izole edilmeden kaynaştırılması gereğinden, yani özel gereksinimlilik için eğitim politikalarında sadece "içerik/madde" oluşturmaktan çok, "özel” eğitim politikaları geliştirilmesi gerektiğinden söz etmesi olarak görülebilir. Buraya kadar yapılan değerlendirmeler sonucunda Türkiye'de eğitim politikalarında kavram ile doğrudan ya da dolaylı ilgili olan yönetmeliklerin temel nitelikleri şöyle sıralanabilir:

Yönetmelikler, ilgili yasalarda ayrıntısına yer verilmeyen özel gereksinimli olma kavramına dair boşlukları doldurmak açısından olumlu ve anlamlı içerikler taşımaktadır. Bu kavrama hem doğrudan hem de dolaylı olarak yer veren yönetmeliklerin olması, hatta birinin özellikle özel gereksinimli bireyler için oluşturulmuş olması önemlidir. Kavramın, farklı terimlerle ele alınması içeriği bütünleştirememekte, aksine kavram kargaşasına neden olmaktadır. Ancak özel gereksinimli olma kavramı ilgili yapılan düzenlemelerin uygulama/yol ve yöntemlerinin kullanışlı ve pratik biçimde aktarıldığı görülmektedir. Yönetmeliklerde “özel gereksinimli" kavramının içinin muhtaç/sakat olarak doldurulmaması, aksine çözümler ve uygulamaların "izole edilmeden kaynaştırma" önerisi ile sunulması önemli bir kazanım olarak değerlendirilebilir.

\section{Kalkınma Planları}

Eğitim politikalarına yön veren diğer bir önemli kurum Kalkınma Bakanlığı'dır. Kalkınma Bakanlığı hazırladığı beş yıllık kalkınma planları ile ülkenin değişik sektörlerindeki gelecek beş yıllık faaliyetlere 1şık tutmaktadır (Usta, 2015, s. 59). Bu çalışma kapsamına alınan 10. Kalkınma Planında (2014-2018) eğitim hedefleri; "düşünme, algılama ve problem çözme yeteneği gelişmiş, demokratik değerleri ve milli kültürü özümsemiş, paylaşma ve iletişime açık, sanat ve estetik duyguları güçlü, özgüven ve sorumluluk duygusu ile girişimcilik ve yenilikçilik özelliklerine sahip, bilim ve teknoloji kullanımına ve üretimine yatkın, bilgi toplumunun gerektirdiği temel bilgi ve becerilerle donanmış, üretken ve mutlu bireylerin yetişmesi" olarak açıklanmıştır. 2014-2018 yılları arasında gerçekleştirilmek istenen eğitim hedefleri arasında pek çok konu ile birlikte özel gereksinimli olma kavramına da yer verilmiş;

-"ilk/ortaöğretimde başta engelliler ve kız çocukları olmak üzere tüm çocukların okula erişiminin sağlanması",

-“özel eğitime gereksinim duyan engellilerin ve özel yetenekli bireylerin bütünleştirme eğitimi doğrultusunda uygun ortamlarda eğitimlerinin sağlanması amacıyla beşeri ve fiziki altyapı güçlendirmesi" gibi hedeflerden söz edilmiştir (T.C. Kalkınma Bakanlığı, 2015).

Daha önceki Kalkınma Planlarında özel gereksinimli olmanın daha çok uluslararası yükümlülükler (Birleşmiş Milletler ve Avrupa Birliği) çerçevesinde ele alındığı,

-Dördüncü Kalkınma Planında tıbbi modelin (durumu özel gereksinimden ziyade sakatlık olarak ele alma), 
-Beşinci ve Altıncı Kalkınma Planlarında "özür" kavramına dönüştüğü ama yine eğitimlerinden ziyade tedavi ve rehabilitasyon hizmetlerinden söz edildiği,

-Yedinci ve Sekizinci Kalkınma Planlarında sosyal model çerçevesinde ele alındığı, aralarında konuyla ilgili eğitimcilerin de yer aldığı paydaşlardan oluşan Özürlüler Yüksek Kurulu'nun kurulduğu, bu kapsamda Özürlüler Şurası'nın yapıldığı ve eğitim programlarının, kaynaştırma programlarının, izleme ve uygulama süreçleri içeren özel eğitim ilkelerinden söz edildiği, haklar kapsamında "eğitim"in de yer aldığı,

-Dokuzuncu Kalkınma Planında eğitime erişim sorunlarına, fırsat eşitliğine değinildiği,

-Son kalkınma planında ise buna altyapının güçlendirilmesinin de eklendiği görülmektedir (Gül ve diğerleri, 2016, s. 788-792).

Geleceğe 1şık tutan kalkınma planları değerlendirildiğinde, en son hazırlanan iki plandan biri olan 10. Kalkınma Planında özel gereksinimliliğe kısıtlı olarak değinildiği görülmektedir. Okula erişimin, bütünleştirme eğitiminin, uygun eğitim ortamlarının sağlanmasının ve altyapının önemine vurgu yapıldığı, ancak bunların nasıl gerçekleştirileceğine dair gereken modellere, detaylara, açıklamalara yer verilmediği izlenmektedir. Bu yönüyle kalkınma planlarının şekilci bir yapı içerdiği, uygulanabilir ve sürdürülebilir olma noktasında zayıf kaldığı söylenebilir. Benzer durum 11. Kalkınma Planı'nda da görülmektedir. Planın kapsamındaki "Nitelikli insan, güçlü toplum" başlı̆̆ı altında özel politika gerektiren çocuklar, yaşlılar, kadınlar gibi grupların içinde özel gereksinimlilere de yer verildiği ve toplumun tüm kesimlerini kapsayan bir yaklaşım gözetilmeye çalışıldığı izlenmektedir. Aynı başlık altında özel gereksinimli bireylerin işgücü piyasasına girme ve kalma sorunlarına da değinilmiş, bu piyasada yaşanan dijital dönüşüm ve teknolojik değişimlerin dikkate alınmasına, bu bireylere insana yaraşır iş fırsatları sunulmasına vurgu yapılmıştır. "İstihdam ve çalışma hayatı" başlığı altında özel gereksinimlilerin meslek edinmelerine yönelik uzaktan eğitim programları geliştirileceğinden ve sağlanacak iş bulma fırsatlarından söz edilmiştir. "Ailenin güçlendirilmesi" başlığı altında özel gereksinimli bireylerin bakım ve imkânlarının kaliteli, ekonomik ve erişilebilir olmasından, bu hizmetlerin standartlaştırılmasından, sosyal/spor etkinliklerine katılımlarının sağlanmasından bahsedilmiştir. "Kırsal kalkınma" başlı̆̆ı altında ise özel gereksinimli bireylere yoksullukla mücadele konusunda öncelik verileceğine vurgu yapılmıştır. 11. Kalkınma Planı incelendiğinde, özel gereksinimli olma ile ilgili bileşenlere daha detaylı yer verildiği, ancak her bileşen için öne sürülen yol ve yöntemlerin nasıl uygulanacağı konusunda yeterli açıklamanın yapılmadığı görülmektedir (T.C. Cumhurbaşkanlığı Strateji ve Bütçe Başkanlığı, 2019).

10. Kalkınma Planına kadar olan tüm kalkınma planları değerlendirildiğinde, bu kalkınma planlarında var olan duruma anlamlı bir eklemede bulunduğu, ama sadece konunun önemine vurgu yapıldı̆̆ı, işlevsel bir modelleme yapmak konusunda kısıtlı kaldığı izlenmektedir. Ayrıca tüm kalkınma planları incelendiğinde kavramsal bir birlik ve netlik olmadığı görülmektedir. 10. Kalkınma Planı'nda engelli, özel eğitim gereksinimi duyan ve özel yetenekli bireylerden söz edildiği; bunların tümünün "bütünleştirilmesi" gerektiği ve çatı oluşturacak bir kavrama ihtiyaç duyulduğu da yapılabilecek değerlendirmeler arasındadır. 11. Kalkınma Planında ise bu durumun düzenlendiği ve "engelli" kavramının tek ve kapsayıcı biçimde kullanıldığı, ancak özel gereksinim kavramının geçirilmediği gözlenmektedir.

\section{Strateji Planları}

Stratejik planlar kurum ve kuruluşlarının orta ve uzun vadeli amaçlarını, temel ilke ve politikalarını, hedef ve önceliklerini, bunlara ulaşmak için izlenecek yöntemleri içeren temel politika belgeleridir (Yılmaz ve Dalkıran, 2012, s. 66).

Eğitim sistemini işlev ve pratiklere indirgeyerek ele alan ve 2023 eğitim vizyonu 1şığında Milli Eğitim Bakanlığı Strateji Geliştirme Başkanlığı tarafından hazırlanan 2019-2023 Strateji Planı'nda, "nicelik ve erişimle ilgili sorunları geride bırakan" Türk Milli Eğitim Sisteminin ileriye yönelik "nitelik" devrimini gerçekleştirmek amaçlanmıştır. Bu planlamada özel gereksinimli çocuklar, özel politika veya uygulama gerektiren dezavantajlı gruplar kapsamında ele alınmış ve engellilerin eğitime katılımını yaygınlaştırılacak politika ve stratejiler geliştirilmesi, uygulanması ve koordine edilmesi, özel yetenekli çocukların bu 
niteliklerinin korunması ve geliştirilmesi için özel eğitim programlarının tasarlanması/uygulanması, Milli Eğitim Bakanlığı Bilgi İşlem Sistemi (MEBBİS) ile engelli bireylere ulaşılması ve onlarla ilgili bilgi iletişim ağının kurulabilmesi, engelli çocuklar için eğitimde adalet temelli yaklaşım modelinin belirlenebilmesi, okulların engelli çocukların kullanımına uygun hale getirilmesi, özel eğitim ihtiyacı olan çocuklara yönelik hizmetlerin kalitesinin arttırılması, özel eğitim gereksinimi olan bireylerin tespit/tanı sisteminin yeterli hale getirilmesi, öğretmen yönetici ve ailelerin özel eğitim farkındalığının yükseltilmesi, yerel yönetimlerin yeterli düzeyde özel eğitim merkezi kurmasının sağlanması, özel eğitim ile ilgili verilen hizmetlerin kalitesinin denetlenmesi gibi hedeflerden söz edilmiştir (T.C. Milli Eğitim Bakanlığı, 2019b).

2019-2023 Strateji Planı eğitimde özel gereksinimli olma kavramına ne kadar ve nasıl yer verdiği noktasından incelendiğinde değerli bir yaklaşım farklılığı ile karşılaşılmakta; nicelik ile değil, nitelik ile ilgilenilmesi gerektiğine vurgu yapıldığı görülmektedir. Özel gereksinimli olma kavramı "dezavantajlı grup" adı altında toplanıp adlandırılmıştır. Ayrıca strateji planı kapsamında, özel gereksinimli çocukların eğitimleri noktasında etkili olabilecek tüm bileşenlerin ele alındığı ve anlamlı hedefler noktasından düzenlemeler yapıldığı görülmektedir. Bu durumun geleceğe yönelik cesaret veren bir yaklaşım olduğunu söylemek mümkündür.

\section{Milli Eğitim Şuraları}

Milli Eğitim Şuraları, Türkiye'de eğitim alanına ilişkin politika üretmek için ulusal düzeyde ve bir yönetmeliğe dayalı olarak gerçekleştirilen en ciddi, kapsamlı ve işlevsel toplantılardır (Yılmaz, 2004, s. 176). Dört yılda bir toplanan Milli Eğitim Şuralarında, Milli Eğitim Bakanlığı'nın eğitim ve öğretim ile ilgili konuları incelenmekte ve öneri/tavsiye niteliğinde kararlar alınmaktadır.

1961-1980'li yılları arasında yapılan Milli Eğitim Şuraları incelendiğinde; özel gereksinimlilikten "rehberlik" kavramı ile söz eden ilk Şura'nın 1739 sayılı Milli Ĕ̆itim Temel Kanunu'na da kaynaklık eden 8. Milli Eğitim Şurası olduğu görülmektedir (Durmuş, 2018, s. 445). Dokuzuncu Şura'da özel gereksinim kavramına değinilmediği, 10. Milli Eğitim Şurası'nda ise özel eğitim gerektiren çocukların tanınması ve özel eğitim programlarına geçirilmesinin temel eğitim süresince yapılacağı kararı alındığı izlenmektedir (Üçler, 2006, s. 50).

Eğitimcilerin eğitimlerinin işlendiği 11. Şura'da “Üniversiteler içinde alanla ilgili, laboratuvar ve uygulama görevi yapacak, Millî Eğitim Bakanlığına bağlı özel eğitim kurumlarının oluşturulmasından ve özel eğitime muhtaç çocukların tanınıp gereken önlemlerin alınmasından" söz edilmektedir. Ayrıca öğretmenlere özel eğitime muhtaç çocukların tanıtılmasına, bu çocukların nasıl eğitileceğinin özür gruplarına göre aktarılmasına da değinilmiştir. 11. Şura'da özel eğitim uzmanı tanımına yer ayrılarak, “özürlü öğrencilere teşhis koyma, belirlenen özürlere göre öğrencileri kümeleme ve uygun eğitim programlarına yerleştirme, eğitimlerini planlama, ilgili paydaşlarla işbirliği yapma" gibi sorumluluklarına vurgu yapılmıştır. Ayrıca özel eğitim uzmanlarının eğitilmesi için model tekliflerinin yapıldığı, yüksek lisans eğitimi gerekliliğinden ve almaları gereken derslerden söz edildiği görülmektedir (Eriş, 2006, s. 188, 190, 207; T.C. Milli Eğitim Bakanlığı, 1982).

Üstün veya özel yeteneklilerin eğitimi ile ilgili olarak ilk tavsiye kararının ise 12. Milli Şura'da alındığı ve zekâ seviyesi yüksek çocuklar için özel sınıfların açılması ve özel eğitime muhtaç çocukların eğitimine önem verilmesi, fen liselerinde kuruluş amaçlarının gerçekleştirilmesi yanında özel yetenekli ve üstün zekâlı çocukların eğitimine imkân sağlamak üzere özel programların uygulanması ve öğretmen donatım ve altyapı imkânları tamamlanmadan yeni fen liselerin açılmaması önerilerinde bulunduğu görülmüştür (T.C. Milli Eğitim Bakanlığı, 1988; Üçler, 2006, s. 71,112).

Durmuş'un (2018, s. 446), T.C. Milli Eğitim Bakanlığı'ndan (2006) aktardığına göre, 17. Milli Eğitim Şurası'nda özel gereksinimli çocukların eğitimi konusunda imkânların ve kaynakların arttırılmasına, farklı meslek alanlarının tanımlanmasına, kaynaştırma kavramının sınırlarının çizilmesine, yasal düzenlemelerin ve ailelere yönelik eğitim çalışmalarının önemine vurgu yapıldığı görülmektedir. Kaynaştırma eğitiminden detaylı söz edilmekte, özel yetenekli olmak da bir özel gereksinim sayılarak desteklenmekte, tanılama ve 
yönlendirme yapılabilmesi için ölçme araçları geliştirme ve uyarlama çalışmalarının gerçekleştirilmesi gerektiğine, eğitimde eğitim ortamı ve materyal olanaklarının daha iyi hale getirilmesine işaret edilmektedir. Bu konular özel eğitim olarak ayrı bir başlık altında ele alınmaktadır.

18. Milli Eğitim Şurası'nda spor tesislerinin özel gereksinimli öğrencilerin de faydalanmasını imkân verecek şekilde standartlara uygun planlanması mevcut tesislerin de iyileştirilmesi üzerinde durulmaktadır. 19. Milli Eğitim Şurası'nda mevcut okulların fiziki ortamlarının özel gereksinimli bireylerin ihtiyaçlarını karşılayacak şekilde tasarlanıp tasarlanmadığının kontrol edilmesi, varsa aksaklıkları giderecek önlemler alınması önerilmiştir (T.C. Milli Eğitim Bakanlığı, 2014).

Türkiye'de Milli Eğitim Şuralarının yanı sıra Özürlüler Şurası adı altında dört toplantı daha yapılmıştır. 3 Aralık 1999 tarihinde gerçekleştirilen 1. Özürlüler Şurası'nın teması “Çağdaş Toplum, Çağdaş Yaşam ve Özürlüler" olarak belirlenmiştir. Özel gereksinim ilgili tüm kesimleri bir araya getiren ilk platform olması ve ilgili tüm konuların ilk defa bir arada görüşülmesi ve tartışılması nedeniyle özel gereksinimliler açısından önemli bir şûradır. En son 16 Kasım 2009'da yapılan 4. Özürlüler Şurası'nın amacı ise, “özürlü ve özürlülük konusunda her türlü görüş ve çözüm önerilerini tartışmak, ulusal politikalara esas olacak ilke ve programlar oluşturmak, kamuoyunun bu konuda bilinçlenmesine katkıda bulunmak, ulusal ve uluslararası alanlardaki görüş, düşünce ve gelişmelerin aktarılmasını, tartışılmasını sağlamak" olmuştur (T.C. Milli Eğitim Bakanlığı, 2010b).

Cumhuriyetin kuruluşundan bugüne uygulamada olan şuraların çok geniş bir yelpazede gündem oluşturduğu, özellikle ilk yıllarında; öğretim programları, ders kitapları, öğretmen yetiştirme, ana dilde eğitim, Milli şuur ve tarih bilinci, demokrasi eğitimi, okullaşma gibi başlıklarda çalışmalar yapıldığı görülmektedir. 1980'li yıllardan itibaren ise bunlara ek olarak kararların çeşitlilik gösterdiği; okul öncesi eğitim, özel eğitim, rehberlik gibi başlıklarıyla birlikte özel gereksinim konusuna da değinildiği görülmektedir. Araştırma sonuçlarından elde edilen bulgular doğrultusunda; “Diğer temalar" başlığı altında incelenen temalardan "Din Kültürü ve Ahlak Eğitimi", Türkçe Öğretimi", "Özel Eğitim" ve "Teknoloji Eğitimi" en çok öne çıkan kategoriler olmuştur. "Diğer temalar" başlı̆̆ı altında alt kategorileri olmayan temalar sekiz temada bütünleştirilmiştir. Belirlenen temalara ait alınan toplam gündem sayısı 60 olup; “Din ve Ahlâk Eğitimi" ve "Türkçe Öğretimi" nin 12, "Özel Eğitim" ve "Teknoloji Eğitimi" nin 8, "Bilim, Sanat, Spor" konularının 6, "Tarih Öğretimi/Milli Şuur" ve "Okul Güvenliği/Okul Sağllğı" nın 5, "Değerler Eğitimi/Vatandaşlık/Demokrasi Eğitimi" konularının da 4 şurada görüşüldüğü anlaşılmaktadır (Kılıç ve Güven, 2017, s. 595, 598).

Bundan sonraki şuralara hazırlık aşamasında ülke genelinde eğitim-öğretim süreci ve uygulamalarıyla ilgili kapsamlı araştırmalar yapılarak ya da araştırmalardan yararlanılarak Milli Eğitim için ihtiyaç duyulan ve öncelikli olan konuların belirlenmesi gerekmektedir. Özellikle Kılıç ve Güven'in (2017) bulgularına dayalı olarak bugüne kadar yapılan şuralarda nispeten daha az ele alınan özel gereksinimli olma başlığına sonraki şuralarda daha geniş ve öncelikli yer verilmesi uygun görünmektedir. Bunun yanı sıra şuraların daha tematik hale getirilmesi "özel gereksinimli bireyler" başlığı altında bir şura gerçekleştirilmesi anlamlıdır. Ayrıca Milli Eğitim Şûralarında alınan kararların uygulamalara ne derece yansıdığın belirlemeye yönelik araştırmalar yapılması, politikaların uygulamaya ne derece yansıdığının yani işlevsel olup olmadığının anlaşılması için son derece önemlidir.

Türkiye'deki ulusal eğitimin sorunlarının belli aralıklarla en üst seviyede tartışıldığı toplantılar olan Milli Eğitim Şuralarının geneline bakıldığında; 1961-1980 yılları arasında özel gereksinimliliğin kısıtlı olarak ele alındığı, ancak sonrasında kavram kargaşası taşımakla birlikte kamuya farkındalık yaratacak düzeyde olduğu, sonrasında ise kavramın hem önemli bileşenlerini hem de spesifik detaylarını inceleyen yapıya sahip oldukları görülmektedir. Ayrıca tamamen bu konunun ele alındığı özürlüler şuralarının düzenlenmiş olmasının, kavramı içeren eğitim politikalarının oluşturulmasına yapacağı katkı tartışılmazdır. Çünkü Milli Eğitim Şuraları, eğitim-özel gereksinim ilişkisinin ortaya konacağı en uygun politika belgeleridir. Bir diğer açıdan bakıldığında, son yıllara doğru daha nitelikli ve yaratıcı içeriklere yer verildiği görülmektedir. Hemen her şurada özel gereksinim kavramına değinilmiş olması, eğitim politikaları hususunda olması gerektiği 
kadar öncelik aldığını göstermektedir. Şuralarda, özel gereksinimli olma kavramının tartışıldığı tüm ortamlarda dikkat edilmesi gerektiği gibi, özel gereksinimli bireylerin ve ailelerinin temsilcilerine de yer verilmesi gerektiği de atlanmaması gereken bir konudur.

\section{Çalıştaylar}

Çalıştay, bilim insanlarının ve uzmanların bir konuda ön hazırlık yapmak üzere katıldığı inceleme ve değerlendirme toplantıları olarak tanımlanabilir (Yılmaz, 2004). Eğitim içerikli yapılan her çalıştay raporu bir politika belgesi sayılmamakta, ancak bazı çalıştayların değerlendirme sonuçlarından eğitim politikalarının düzenlenmesinde yararlanılabilmektedir. 2013 yılında Türkiye Engelsiz Bilişim Platformu organizasyonuyla ve İstanbul Üniversitesi ev sahipliğinde gerçekleştirilen “Uluslararası Katılımlı Engelsiz Bilişim 2013 Sempozyumu" kapsamında Milli Eğitim Bakanlığı Yenilik ve Eğitim Teknolojileri Genel Müdürlüğü (YEGİTEK) işbirliği ile "Fırsatları Artırma ve Teknolojiyi İyileştirme Hareketi (FATİH) Projesi² ve Engelliler Çalıştayı" gerçekleştirilmiştir. Bu çalıştayın ilki 2012 yılında Manisa'da düzenlenen sempozyumda gerçekleştirilmiş olup konuya katkı sağlamış ve içeriğinin ülkenin eğitim politikasını etkileyecek modern bir geçiş sağlayacağı öngörülmüştür. Çalıştayda kullanılan ve yazılı olarak da paylaşılan tartışma yönteminde özel gereksinimli olma, engellilik kavramının çatısı altında ele alınmış, bu başlı̆̆a öncelik tanınacağı belirtilmiş, MEB'in internet altyapı uygulamalarında (FATİH projesi, Eğitim Bilişim Ağı [EBA], e-içerik vb.); "Engelliler için özel uygulamalar neler olmalıdır?", "İçerikten engelliler nasıl faydalanır?", "Farklı nasıl çalışmalar yapılmalıdır?" gibi sorulara yanıt aranmıştır. Ayrıca FATİH projesinden çıkarılan 'engellilere ilişkin uygulamalar' başlığı eleştirilmiş; bu durumun özellikle FATİH projesinin temel çıkışına aykırı olduğu, özellikle engellilerin yararlanacağı tablet uygulamalarının dünyadaki örneklerinin incelenmesi ve bu uygulamaların FATIHH projesi ile bütünleştirilmesi gerektiği belirtilmiştir. Zihinsel engellilerin, görme, işitme gibi engelleri olan çocukların ve üstün yeteneklilerin de bu projeye entegre edilmesi gereğine vurgu yapılmıştır. Sonuç sunumunda fırsat eşitliğine özellikle değinilerek engelli bireylerin de devreye alınması gerektiği belirtilmiş, 'engelliler adına' değil, 'engellilere uygun içerikler' geliştirilmesi gerektiği konusu netleştirilmiştir (Türkiye Engelsiz Bilişim Platformu, 2013, s. 16, 23, 24).

2013 yılında düzenlenen sonraki çalıştayda ise eğitimde fırsat içeriği ile ortaya çıkan projelerde engellilere yer verilmesinin öneminden söz edilmiş, bu kez çalıştay gruplarından ikisi görme engelliler ağırlıklı katılımcılardan, biri ise özel olarak engel ve otizm çalışan katılımcılardan oluşturulmuştur. Çalıştayın hedefi "engellilerin bilişim teknolojilerinden beklentileri ve FATİH Projesi'nin bunu nasıl karşılayacağı" sorusuna yanıt vermek olarak belirlenmiştir. Sonuç Bildirgesi'nde Milli Eğitim Bakanlığı'nın önemli projelerinden FATİH Projesi'nin engelliler için de bir fırsat olacağı, bu projenin engelli bireylerin eğitim sistemine aktif olarak katılmasının yolunu açacak bir proje olarak görülmesi gerektiğine vurgu yapılmıştır. Bunun sağlanması için ilgili tüm paydaşların (kurumlar, üniversiteler, STK'lar) bir araya gelmesi gerektiğine değinilmiş, engellilere uygun ekipman sağlanmasının, eğitimcilerin eğitilmesinin, pilot çalışmalar tasarlanıp denenip denetlenmesi ve revize edilmesinin önemi belirtilmiştir (Yamamoto, 2014, s. 3, 5).

2016 yılında gerçekleştirilen 3. Eğitim Teknolojileri Zirvesi'nde atölye çalışmaları, paneller ve oturumlar düzenlenmiş, eğitim teknolojileri ile ilgili çalışan paydaşlar bir araya gelmiştir. Zirvede MEB tarafından 2010 yılından beri yürütülen FATİH Projesi'ne değinilmiş, EBA ${ }^{3}$ eğitim portalına vurgu yapılmıştır. Öğrencilere sosyal ağlar üzerinden ulaşılırken kodlama eğitimi, mobil eğitim, oyun tabanlı öğrenme, STEM, robotik ve engelsiz bilişim konularında çalışıldığı belirtilmiştir. Bu kapsamda gerçekleştirilen 75 bildiri sunumundan sadece 3 tanesinin "engel" başlıklı olduğu (İşitme Engelliler İçin 3. Sınıf Fen Bilimleri Ders İçeriği, Engelli Bireylerin Afet ve Acil Durum Risklerine Karşı Farkındalık Kazandırmak Amacıyla Bir Öğrenme Yönetim Sisteminin Geliştirilmesi ve İşitme Engelli Öğrenciler İçin Yeni Bir Eğitim Yaklaşımı Olarak STEM ve Örnek Bir Uygulama: Mucit) görülmüştür (T.C. Milli Eğitim Bakanlı̆̆ı, 2017, s. 5, 7, 17).

\footnotetext{
${ }^{2}$ FATİH Projesi: Her öğrencimizin en iyi eğitime kavușması, en kaliteli eğitim içeriklerine ulașması ve eğitimde fursat eșitliğinin sağlanması için tasarlanmıș olan FATïH Projesi, eğitimde teknoloji kullanımıyla ilgili dünyada uygulamaya konulan en büyük ve en kapsamlı eğitim hareketidir (T.C. Milli Eğitim Bakanlığı, 2020b).

${ }^{3}$ Eğitim Bilişim Ağı (EBA): Öğretmenler ile öğrenciler arasında iletişim kurmak, eğitim hayatları boyunca kullanabilecekleri materyalleri sağlamak üzere kurulan eğlenceli ve eğitsel elektronik içerik ağıdır (T.C. Milli Eğitim Bakanlığı, 2020a).
} 
Çalıştayların, kamu sorunları için akademik zihinlerden çıkacak yaratıcı teorik ve uygulamalı fikirleri barındıracağı ortadadır. Spesifik olarak eğitim politikalarında özel gereksinimli olma ile ilgili yapılan çalıştaylar sayılıdır. Yukarıda detayları aktarılan bu çalıştayların konuya dair başarılı içerikler ortaya koyduğu, bu sayede özel gereksinimli bireylerin fırsat eşitliğine ajitasyondan uzak çözümler üretildiği anlaşılmaktadır. Özel gereksinimlilerin 'yardıma ihtiyacı olan bireyler' olması noktasından değil, 'kendilerine uygun içeriklere ihtiyaç duyduklarına' vurgu yapan bu çalıştaylarda özel gereksinimli bireylere ve bu konuda çalışan uzmanlara yer verilmesi, temsil edilme anlamında çok olumlu bir durumdur. Özellikle eğitim politikalarının geliştirilmesi noktasında, durumu yaşayan ve durum hakkında doğrudan çalışan kişilerin bulunmasının sürece önemli bir katma değer katacağı düşünülmeli ve politika belgelerinin oluşturulmasında buna dikkat edilmesi gerektiğinin altı çizilmelidir.

Konu ile ilgili çalışan teorisyen ve uygulamacı akademisyenlerin sayısının oldukça fazla olduğu ve yayın miktarının da her geçen gün arttığı bilinmektedir. Ancak burada politika yapıcıların politika düzenlemelerini oluştururken, konuya hâkim akademisyen paydaşları da kapsamına almaları gerekmektedir. Yoksa hem politika belgelerinin maddelerinin, hem de akademik çalışmaların sonuçlarının sadece konunun önemine işaret edip, yeterli çözüm uygulaması sunamamasının önüne geçilmesinin mümkün olamayacağı düşünülmektedir. Bu çıkarımlar doğrultusunda, çalışmanın bulguları, araştırma sorularına göre şu şekilde özetlenebilir:

1. Türkiye'de halen yürürlükte olan ilk ve orta öğretim düzeyindeki eğitim politikası belgelerinde özel gereksinimli olma kavramina ne kadar yer verilmektedir?

Çalışmadan çıkarılan sonuçlara göre Türk Eğitim Politikalarında özel gereksinimli olma kavramına yeterince değinilmediği görülmektedir. Bu noktada politika belgeleri arasında bir dengesizlik olduğu, bazı belgelerin özel gereksinimli olma konusuna yeterince değinirken, bazılarının ise bütüncül yaklaşamadığı ve dolayısıyla boşluklar bıraktığı düşünülmektedir. Bu bakımdan araştırmanın ilk sorusuna verilen cevap olumsuzluk içermektedir.

2. Türkiye'de halen yürürlükte olan ilk ve orta öğretim düzeyindeki eğitim politikası belgelerinde özel gereksinimli olma kavramı ağırlıkla hangi açılardan ele alınmaktadır?

Çalışmanın sonuçlarına göre Türk eğitim politikalarında var olan politika belgeleri özel gereksinimli olma kavramına "maddi yardım sağlama ve destek olma" ağırlıklı yani sonuca odaklı olarak değinmekte, özel gereksinimli olmanın bir yaşam biçimi olduğu gerçeğini gözden kaçırıp süreci ve süreçte ortaya çıan erişim, eğitimci, eğitim ortamı, tanılama ve değerlendirme, aileler, eğitim programı ve tüm bunların devamlılığı gibi sorunları dağınık ve parçalı biçimde ele almaktadır. Dolayısıyla araştırmanın ikinci sorusuna verilen cevap her bileşenin yeterince ele alınmadığına, eksik bırakılan ve dengeli aydınlatılamayan noktaların olduğuna vurgu yapmaktadır.

\section{Türkiye' de halen yürürlükte olan ilk ve orta öğretim düzeyindeki eğitim politikası belgelerinde özel gereksinimli olma kavramına ilişkin yaklaşım çağdaş nitelikte midir?}

Çalışmadan çıkarılan sonuçlara göre Türk eğitim politikalarına dair politika belgelerinde özel gereksinimli olmaya dair geliştirilen strateji ve yöntemlerin büyük kısmı uygulanabilir ve sürdürülebilir durumda değildir. Politika belgelerinin çoğunda, kavramın önemine değinilmiş, ancak var olan eksik ve gereksinim durumları ile ilgili neler yapılabileceğine dair pratik ve uygulanabilir yöntemlere fazla yer verilmemiştir. Bunun araştırmanın ilk sorularında cevaplandığı gibi, gereksinimlerin iyi belirlenememesi ve kapsayıcı, bütüncül bakış açılarının kazanılamamasından kaynaklandığı düşünülmektedir. Dolayısıyla araştırmanın son sorusuna verilen ve çağdaş nitelikte bir eğitim politikasının karşılaması gereken en önemli kriterlerden biri olan uygulanabilirliğin düzeyine dair cevap olumsuz içerikli olmakta ve bu yönüyle geleneksel yaklaşımın dışına çıkamayan bir özellik göstermektedir. 


\section{Sonuç ve Öneriler}

Türkiye'de eğitim sisteminde ilk ve ortaöğretim düzeyleri bağlamında özel gereksinimli olma kavramına ilişkin yaklaşımlarının temel niteliklerini değerlendirmek amacıyla gerçekleştirilen bu çalışmada önemli olduğu düşünülen sonuçlara ulaşılmıştır. Değerlendirmeler, eğitimde eşitlik ilkesinden dayanak alınarak yapılmıştır. Yani çalışma "özel gereksinimli olma kavramı, toplumu oluşturan tüm bireylerin eşit haklara sahip olması gereken eğitim hakları kapsamında ele alınması, farkındalık sağlanması, uygulanabilir yol ve yöntemlerle devam ettirilmesi gerekli bir kavramdır" önermesi üzerinden gerçekleştirilmiştir. Özel gereksinimli olma kavramının çerçevesi aktarılırken kavram kargaşasından uzak durulmasına, ortak dil ve kavramların farkındalığı daha da yükselteceğine, eğitim politikaları ile ilgili belgelerin kapsamında özel gereksinimliliğe yer verilme düzeyi kadar, niteliğe de bakılması gerektiğine vurgu yapılmıştır. Kavrama değinen politika belgelerinin ilgili madde ve içeriklerinin, önerilen yol ve yöntemlerin uygulanabilirliği ve sürdürülebilirliği üzerinde durulmuştur. Gerek kuramsal, gerekse Türkiye'deki eğitim ile ilgili politika belgelerine dayalı olarak yapılan değerlendirmeler ışığında elde edilen sonuçlar şöyle sıralanabilir:

-Araştırma kapsamında ele alınan konuya dair literatür ve politika belgelerinin tamamında özel gereksinimli olma ile ilgili tek bir çatı kavram oluşturulamadığı, bunun da kavram kargaşasına yol açtığı görülmüştür. Kavramsal sorunların ve tutarsızlığın özel gereksinimli olma ile ilgili uygulanabilirliği düşük yöntemleri yaratması kaçınılmazdır. Bu nedenle eğitim politikaları ile ilgili tüm çalışmalarda, kavram için netlik sağlanması ve kavramın son hali için 'dezavantajlılık, özel gereksinim, sakatlık, muhtaçlık, özürlü olmak, özel eğitim gerektirmek’ gibi içeriklerden birisi üzerinde karar verilmesi, esasen literatürde kullanıldığı haliyle özel gereksinimli olma biçiminde ifade edilmesi gerekmektedir. Kavramı zayıf gösteren ve sadece "zavallı, yardım alamaz/edilemez " gibi bir anlama sahip olan yanıltıcı kavramların (sakat, muhtaç, özürlü) kullanılmamasına, içinde uygulamayı da barındırıp öneren yapıcı kavramların öne çıkmasına dikkat edilmelidir. Bu nedenle tüm politika belgelerinin içerikleri bu açıdan gözden geçirilmelidir. Kavramsal tutarlılık, konunun bilgisine ve farkındalığına yansıyacak ve algıyı/bakış açısını olumlu/yapıcı yönde geliştirecek bir değişim olarak ciddiye alınmalı ve sonuçlarından bu niyetle yararlanılmalıdır.

-Konuya dair sorunlar, haklarında oluşturulan politikalar, onaylanmıs politika belgeleri ve yapılan akademik çalışmalarla çözüme ulaştırılabilir. Bu çözümlerin üretilebilmesi için ise kavramın iyi anlaşılması, iyi tanımlanması, farklı durumlara dair alt başlıkları ayrılabilmesi, farklı koşullarda ve zamanlarda ele alınabilir ve uygulanabilir olması gerekmektedir. Hedef, yol ve yöntem olarak özetlenebilecek politika sürecinde, kavramın tanınması ve tanımlanmasından sonra atılması gereken ikinci önemli adım gereksinim analizidir. Çalışmada özel gereksinimli olma kavramının, eğitim politikalarında ne ölçüde ve hangi niteliklerde ele alındığı değerlendirilmiştir. Kavramın ele alınıp uygulanması ya da bu haklara erişilmesi ile ilgili yaşanan sorunların, özel gereksinimli olma kavramına dair ihtiyaç analizinin yeterince yapılmamış olmasından kaynaklanabileceği düşünülmektedir. Konuya ilişkin yapılan akademik çalışmaların bazılarında gereksinimlerin ortaya konulduğu, açıklanmaya ve tarif edilmeye çalışıldığı görülmektedir. Ancak çalışmaların birçoğu sadece özel gereksinimli olmanın önemli bir kavram olduğuna değinmek ve tarihçesinden söz etmekle yetinmiştir. Çalışmaların bir kısmında ise özel gereksinimlilerin ihtiyaçlarına dayalı özgün bir analiz yapılmamakla birlikte, yurtdışındaki iyi örneklerden yararlanılmış ve onların izledikleri yol ve yöntemlerin örnek alınmasıyla (bazıları Türk toplumuna uyarlanmaksızın) gereksinimler belirlenmiştir.

Ayrıca ihtiyaç analizi yapılırken kavram ile ilgili alt başlıkları kapsayıcı biçimde ele alabilen çok az çalışma ve politika belgesi olduğu görülmektedir. Özel gereksinimlilerin eğitime erişimini önemseyen / erişimin üzerinde durmadan sadece eğitim içeriğine vurgu yapan / eğitim özellikleri ve materyallerini önemsemekle yetinen politika belgelerinin sorunları tek tek ele aldığı ve bu konuda kısıtlı kalabildiği görülebilmektedir. Oysa bir eğitim politikası geliştirilirken ve o politika içinde bir kavrama değinirken hedeflerin yani karşılanması gereken gereksinimlerin çok iyi belirlenmesi ve analiz edilmesi gerekmektedir. Gereksinimlerin ortaya iyi konmaması, eksik bırakılması ya da abartılması, uygulamalara, izlenecek yol ve yöntemlere yansıyacak ve konuyu uygulanabilirliği düşük bir sürece sokacaktır. 
-Eğitim politikası geliştirenlerin bu konuyla doğrudan ilgili paydaşlar arasından seçilmesi önemlidir. Çünkü belirlenen gereksinimlerin gruplanması, her birine dair taslakların oluşturulması ve buradan yola çıkılarak ön politikaların geliştirilmesi sürecin önemli adımlarından birisidir. Eğitim politikalarında özel gereksinimli olma kavramına ne kadar değinildiği ile ilgilenen bu çalışmada, ilgili politika belgeleri incelenmiş ve konuyu çalışan kurulların daha üst düzey gruplardan, çoğunlukla politika yapıcılardan seçildiği, ancak bu noktada başka paydaşların da devreye girmesinin önemli olabileceği düşünülmektedir.

Özel gereksinim içerikli politika belgelerinin taslakları geliştirilirken, konuyu 'tanılama' bakımından ele alan akademisyenlerin, 'eğitsel uygulamaları' planlayacak olan uygulamacıların, haklar ve sorumluluklar bakımından söz söyleyecek karar vericilerin/bürokratların ve özel gereksinim ile ilgili tüm yaşantılara hâkim olan temsilci özel gereksinimli bireylerin ve ailelerinin de bu kurullarda söz sahibi olması gerekmektedir. Çalışmada incelenen politika belgelerinin bir kısmının anayasa, yasalar olduğu düşünüldügünde karar verici ve bürokratların yeterince katkıda bulundukları, şuralar, çalıştaylar gibi içeriklerde ise akademisyen ve uygulamacıların söz sahibi olabildikleri; ancak yaşantıyı büyük ölçüde içselleştirip gereksinimlere ve uygulanabilir/uygulanamaz oluş bilgisine tam hâkim olan temsilcilerin yeterince (özel gereksinimliler ve aileleri) söz hakkına sahip olamadıkları görülmektedir. Çocuk Hakları Beyannamesinde çocukların kendilerini ilgilendiren konularda söz hakkına sahip olmalarına değinilmekte, Özel Eğitim Hizmetleri Yönetmeliği`nde (2018) ise ailelerin çocuğu ile ilgili bazı konularda hak sahibi olduğu konular (ulaşım-Madde 63, aile eğitimi alabilme-Madde 18 ve 57, özel eğitim hizmetleri alma-Madde 49, bireyselleştirilmiş eğitim programı geliştirme biriminde yer alma-Madde 47, eğitsel değerlendirme ve tanılama sürecine katılımda bulunma ve bilgi alma/diğer kurum ve kuruluşlarda bulunan aile eğitim programları hakkında bilgi almaMadde 44, özel eğitim değerlendirme kurulunda yer alma-Madde 43, eğitimin başlamasını ya da sonlandırılmasını talep etmek-Madde 40, çocuğuna yönelik gelişim raporları hakkında bilgi edinme-Madde 8 ve ailelerin özel eğitim sürecinin her aşamasına aktif katılmalarının sağlanması-Madde 5) bulunmaktadır. İlgili politika belgelerinin bu konuda ailelere haklar verdiği, ancak politikaların oluşturulması süreçlerinde onlara söz hakkı tanınmadığı söylenebilir.

-Eğitim politikaları geliştirilirken eğitimin önemli bileşenlerinin tamamına yer verilmiş olmasına dikkat edilmesi çok önemlidir. Eğitimin en önemli bileşenleri eğitime erişim, eğitimci özellikleri, eğitim ortamı, eğitim malzemeleri, eğitim programı ve değerlendirme yöntemleri olarak sayılabilir. Özel gereksinimli olma kavramı ile ilgili eğitim politikaları geliştirilirken de eğitimin bu bileşenleri teker teker ve bağlantıları dâhilinde ele alınmalı ve her biri için var olan ihtiyaçların belirlenmesinin ardından, özel gereksinimlilere özgü olarak geliştirilebilecek yol ve yöntemler belirlenmelidir. Ancak var olan politika belgelerinde bu durumun tam olarak sağlanamadığı görülmektedir. Eğitim politikalarına dair belgelerin bazıları bir bileşeni, bazıları birkaç bileşeni ele almakta, bazıları bileşen kavramına girmeden bütüne dair ihtiyaçların olduğuna değinmekte ama bu açıklamalarla kapsayıcı olmaktan uzak kalmaktadır. Dolayısıyla özel gereksinimli olmaya dair eğitim bileşenlerinin tamamını temsil edebilen, açıklayabilen ve uygulamalar yoluyla yol yöntem çizerek bir politika belgesinden bekleneni bütünüyle gerçekleştiren bir belgeye rastlanmamıştır.

-Türk eğitim politikasının gereksinim analizi ve strateji geliştirme açılarından yetersiz kalabildiği düşünülmektedir. Özel gereksinimli olmanın 'muhtaçlık' olduğu algısının kırılması ve bir 'özellik' olarak ele alınabilmesi gerçekleştiğinde belirlenen ihtiyaçların yapısının da değişeceği ve daha işler olabilen stratejilerin kullanılabileceği söylenebilir.

-Türk eğitim politikasının özel gereksinimli olma kavramına yeterince yer verme ve buna dair uygulanabilir politikalar geliştirme konusundaki kazanımlar ve olumlu çıktıları tam olarak ortaya koyamadığı düşünülmektedir.

-Türk eğitim politikaları içinde özel gereksinimli öğrencilerin gereksinimleri ve buna dair yapılacakların iyi ortaya konmamış olması, eğitimin tamamlanmasıyla varılacak noktayı da belirsiz kılmış, bu durum özellikle istihdam sorunları açısından sorun yaratıcı nitelikte bulunmuştur.

-Türk eğitim politikaları ile ilgili belgelerin güncellenmesi ile ilgili gecikme ve sorunlar olduğu, çağın getirdiği dönüşümlerle özel gereksinimli bireylerin ihtiyaçlarının da değiştiği ya da çeşitlendiği açıtır. 
İncelenen politika belgelerinde anılan değişimlere dair güncellenen ya da ilgili kurullar tarafından gözden geçirilenlerin sayısı son derece azdır. Çalışmamızın bu noktaya da dikkat çekmesi hedeflenmektedir.

-Türk eğitim politikaları ile ilgili belgelerinin çalışılması, düzenlenmesi, taslak haline getirilmesi, oluşturulması ve gözden geçirilmesi aşamalarında görev alan, sorumluluk üstlenen kurulların görev, yetki sorumlulukları ile birlikte nasıl belirlendiği açık biçimde tanımlanmamıştır. Bu eksiklik giderilmelidir.

Çalışma kapsamı çerçevesinde elde edilen bu sonuçlara dayanarak bazı önerilerde bulunmak olasıdır:

-Eğitim politikasına dair politika belgelerinde özel gereksinimli olma ile ilgili kavram kargaşası giderilmeli, belgeler tek bir çatı kavram üzerinden oluşturulmalıdır.

-Özel gereksinimli bireylerin eğitime dair gereksinimleri iyi analiz edilmelidir. İhtiyaç analizi iyi yapılan durumlara dair politikaların nitelikli ve kapsayıcı olacağı unutulmamalıdır.

-Yurt dışındaki iyi örneklerden model alınan politika belgelerinin uyarlanması akademik ilkelere bağlı kalınarak yapılmalı, ülkenin ve toplumun yapısına uymayanlar belirlenmeli ve gözden geçirilmelidir. Eğitim politikalarının ulusal politikalar olduğu unutulmadan, Türkiye için özel olarak hazırlanmış, özgün ölçütler ve belgeler üzerinde çalışılmalıdır.

-Politika belgelerinin kapsayıcı olması sağlanmalı, belgelerin tüm ihtiyaçlara bütüncül bakabilmesinin sağlanması konusuna çalışılmalıdır.

-Özel gereksinimliliğe dair eğitim politikalarının taslaklarını oluşturan kurullarda temsilci olarak özel gereksinimlilerin ve ailelerinin de bulunması sağlanmalı, onların yaşam deneyimlerinden yola çıkılarak daha yerinde ihtiyaç analizleri yapılabileceği gerçeği atlanmamalıdır.

-Eğitim politikaları ile ilgili politika belgelerinde özel gereksinimli olmaya hangi açılardan yer verilebileceğine ve hangi yol/yöntemlerin geliştirilebileceğine ilişkin projeler (akademik ve uygulamalı alanlarda) geliştirilmelidir.

-Politika belgelerine dayanak oluşturacak bilimsel çalışmaların sayısı artırılmalıdır.

-Milli Eğitim Bakanlığı kapsamında konuyla ilgili olabilecek belgeleri gözden geçirerek güncelleyen alt kurullar oluşturulmalıdır. Bu kurullar, Bakanlığa düzenli değerlendirme raporları sunarak, belgelerin güncel tutulmasını sağlamalıdır.

-Özel gereksinimli bireylere yönelik “Eğitim Politikalarını Belirleme Kurulu” oluşturulmalıdır. Bu kurul, ilgili belgelerin yapılması, gözden geçirilmesi ve uygulanmasında görev almalı ve ortaya çıkan sorunlarda sorumluluğu üstlenen ve krizleri yöneten bir ekibe sahip olmalıdır.

-Özel gereksinimli bireylere yönelik öğretmen eğitimleri ve hizmet içi eğitimler arttırılmalı, kapsamı genişletilmeli, değerlendirmeler düzenli tekrar edilmeli, staj olanakları genişletilmelidir. Bu eğitimlere dair tüm detayların açık biçimde anlatıldığı, hedeflerinin, kazanım ve göstergelerinin belirtildiği ifadeler politika belgelerine yansıtılmalı, böylece politikalar standart, güvenilir ve sürdürülebilir hale getirilmelidir.

-Üniversitelerde özel gereksinim ile ilgili olabilecek tüm alanlarda anabilim dalları oluşturulmalı, alana ilişkin lisans ve lisansüstü derslere yer verilmelidir. Akademisyenler bu konuya dair çalışmaları için desteklenmeli ve cesaretlendirilmelidir.

-Okul yönetimlerinde özel gereksinimli bireylerin de yer alması sağlanmalı, temsilci oldukları her noktada gereksinimlerin daha iyi belirleneceği ve yerinde önlemler alınıp uygun yöntemler uygulanacağı unutulmamalıdır.

-Özel gereksinimli bireylere yönelik eğitim niteliklerini yükseltmek için kongreler, şuralar, çalıştaylar ve sempozyumların sayısı arttırılmalı, toplantılarda bu kavramın bir alt konu değil, toplantı başlığı haline getirilmesi sağlanmalıdır. Özel gereksinimli olmaya yönelik politikaların konuşulacağı toplantıların da sayısı ve sıklığı arttırılmalı, tüm paydaşların bir araya gelmesi ve güncel politikaların konuşulduğu platformların oluşturulması hedeflenmelidir. 
-Özel gereksinimli bireylerin bilgi teknolojilerini kullanmaları, erişimleri ve uygulama nitelikleri ile ilgili olarak yoğun çalışmalar yapılmalıdır. Bilgi çağının gerekleri, bu bireyler için oluşturulacak politikalara mutlaka yansitılmalıdır.

-Başta yasalar olmak üzere tüm politika belgelerinde özel gereksinimli olma kavramı eğitimin doğal bir parçası olarak yer almalı ve bu konudaki geleneksel anlayış terk edilmeli, yerini ihtiyaçların iyi tespit edildiği, tüm paydaşların devrede olduğu, bütüncül, kapsayıcl, uygulanabilir ve sürdürülebilir modern yaklaşımlara birakmalıdır.

Çalışmadan elde edilen sonuçlar ve bu sonuçlara dayalı olarak sunulan tüm öneriler kuramsal düzeyde tartışılıp geliştirilebilir niteliktedir. Bu çalışma kapsamında, özel gereksinimli olma kavramının önemli bir kamu başlığı olduğuna değinmek, bu kavramın Türkiye eğitim politikası içinde dikkatle ve ayrıntılı bir biçimde ele alınması gerektiğini vurgulamak, var olan politika belgelerini konuya dair incelemek, politikayı ifade eden yol ve yöntemleri gözden geçirmek ve uygulanabilirliği ile sürdürülebilirliğini tartışmak ve gerekli gözden geçirmeleri yapmak ya da özgün yeni belgelerin çalışılması konusuna dikkat çekmek istenmiştir. Çalışmanın alandaki kısıtlı bir noktaya dair gereksinime ve eksiğe işaret etmesi ve konuya dair akademik ya da uygulamalı başka çalışmalara ışık tutması beklenmektedir.

\section{Yazarların Beyanı}

Araştırmacıların katkı oranı beyanı: Bu çalışmada yer alan kaynakların taranması, sentezlenmesi, raporlanması ve düzeltmelerin gözden geçirilmesi birinci yazar tarafından; yapılan sentezin organize edilmesi ve taslak raporun gözden geçirilip düzeltilmesi ikinci yazar tarafından gerçekleştirilmiştir.

Etik Kurul Kararı: Bu çalışma etik kurul kararı gerektirmemektedir.

Çatışma beyanı: Araştırmacılar herhangi bir çıkar çatışması beyan etmemişlerdir.

Destek ve teşekkür: Herhangi bir kurum kuruluştan destek alınmamıştır.

\section{Kaynaklar}

Akçamete, G., Büyükkarakaya, H. S., Bayraklı, H. ve Yıldırım, E. S. (2012). Eğitim politikalarının yansımaları: Genel ve özel eğitim. Journal of Educational Sciences \& Practices, 11(22), 191-208.

Aktel, M. and Erten, Ş. (2017). Türkiye Cumhuriyeti hükümetlerinin engellilik alanına yaklaşımı: Hükümet programları üzerinden bir değerlendirme. Süleyman Demirel Üniversitesi İktisadi ve İdari Bilimler Fakültesi Dergisi, 22(1), 165-177.

Bağcı, E. (2011). Avrupa Birliği'ne üyelik sürecinde Türkiye'de yaşam boyu eğitim politikaları. Ondokuz Mayıs Üniversitesi Ĕ̆itim Fakültesi Dergisi, 30(2), 139-173.

Başbakkal, Z. and Bilsin, E. (2014). Dünyada ve Türkiye'de engelli çocuklar. Ege Üniversitesi Hemşirelik Fakültesi Dergisi, 30(2), 65-78.

Cansever, B. A. (2009). Avrupa Birliği eğitim politikaları ve Türkiye'nin bu politikalara uyum sürecinin değerlendirilmesi. International Online Journal of Educational Sciences, 1(1), 222-232.

Demir, A. (2015). Türkiye'nin AB'ye uyum sürecinde engellilerin değişen konumu. Sosyoloji Dergisi, 31, 59-83.

Durmuş, A. (2018). Millî Eğitim Şûraları ve öğretim programlarında özel yetenekli çocukların eğitimi. Milli Eğitim Dergisi, 47(Özel Sayı 1), 445-448.

Engelliler Hakkında Kanun (2005, 7 Temmuz). Resmi Gazete (Sayı: 25868). Erişim adresi: https://www.mevzuat.gov.tr/MevzuatMetin/1.5.5378.pdf

Engelsiz Yaşama Derneği. (2020). Sayılarla Dünya'da ve Türkiye'de engellilik. Erişim adresi: ey-der.com/anasayfa/turkiye-ve-dunyada-engelliler

Eriş, S. (2006). 1961-1987 yılları arasında gerçekleştirilen Milli Eğitim Şuraları ve alınan kararların uygulamaları. 
(Doktora tezi, Selçuk Üniversitesi, Konya). Erişim adresi: http://acikerisimarsiv.selcuk.edu.tr:8080/xmlui/bitstream/handle/123456789/8168/189408.pdf?sequence=1 \&isAllowed $=\mathrm{y}$

Ertuğrul, B. Ö. (2019). Türkiye'de 1990-2019 yılları arasında uygulanan okul öncesi eğitim politikalarının değerlendirilmesi (Yüksek Lisans Tezi, Hacettepe Üniversitesi, Ankara). Erişim adresi: http://www.openaccess.hacettepe.edu.tr:8080/xmlui/bitstream/handle/11655/21698/Burcu\%20\%c3\%96zk anl\%c4\%b1\%20Ertu\%c4\%9frul\%20YL.pdf?sequence=2\&isAllowed $=y$

Gül, S. S., Cantürk, D. S. ve Gül, H. (2016). Türkiye'de engellilik politikalarında paradigma değişimi: Muhtaç sakattan ihtiyaç sahibi bireye geçiş. Süleyman Demirel Üniversitesi İktisadi ve İdari Bilimler Fakültesi Dergisi, CIEP Özel Sayısı, 785-794.

Kanun Hükmünde Kararname. (2020, 9 Nisan). Vikipedi içinde. Erişim adresi (29 Haziran 2020): https://tr.wikipedia.org/wiki/Kanun_h\%C3\%BCkm\%C3\%BCnde_kararname

Kılıç, Z. ve Güven, S. (2017). Türk Milli Eğitim Şûralarında alınan kararların incelenmesi. Uluslararası Sosyal Araştırmalar Dergisi, 10(53), 588-599.

Milletlerarası Sözleşme. (2009, 14 Temmuz). Resmi Gazete (Sayı: 15137). Erişim adresi: https://www.resmigazete.gov.tr/eskiler/2009/07/20090714-1.htm

Millî Eğitim Bakanlığı Okul Öncesi Eğitim ve İlköğretim Kurumları Yönetmeliği. (2014, 26 Temmuz). Resmi Gazete (Sayı: 29072). Erişim adresi: https://www.resmigazete.gov.tr/eskiler/2014/07/20140726-4.htm

Millî Eğitim Bakanlığının Teşkilat ve Görevleri Hakkında Kanun Hükmünde Kararname. (2011, 14 Eylül). Resmi Gazete (Say1: KHK/652). Erişim adresi: https://www.resmigazete.gov.tr/eskiler/2011/09/201109141.htm

Milli Eğitim Temel Kanunu. (1973, 14 Haziran). Resmi Gazete (Sayı: 14574). Erişim adresi: https://www.resmigazete.gov.tr/arsiv/14574.pdf

Meşe, İ. (2014). Engelliliği açıklayan sosyal model nedir?. Sosyal Politika Çalışmaları Dergisi, 14(33), 79-92.

Montviloff, V. (1990). National information policies. A handbook on the formulation, approval, implementation and operation of a national policy on information. Erişim adresi: https://unesdoc.unesco.org/ark:/48223/pf0000086995

Özdem, G. (2015). Türkiye'de eğitim politikaları alanında yapılan lisansüstü tezlerin incelenmesi (1989-2014). Gaziantep University Journal of Social Sciences, 14(3), 631-646.

Özel Eğitim Hizmetleri Hakkında Kanun Hükmünde Kararname. (1997, 6 Haziran). Resmi Gazete (Say1: 23011). Erişim adresi:

https://orgm.meb.gov.tr/meb_iys_dosyalar/2012_10/10111011_ozel_egitim_kanun_hukmunda_kararnam e.pdf

Özel Eğitim Hizmetleri Yönetmeliği. (2018, 7 Temmuz). Resmi Gazete (Sayı: 30471). Erişim adresi: https://www.resmigazete.gov.tr/eskiler/2018/07/20180707-8.htm

Sağlam, M., Özüdoğru, F. ve Çıray, F. (2011). Avrupa Birliği eğitim politikaları ve Türk eğitim sistemine etkileri. Yüzüncü Yıl Üniversitesi Eğitim Fakültesi Dergisi, 8(1), 87-109.

T.C. Aile, Çalışma ve Sosyal Hizmetler Bakanlığı Engelli ve Yaşlı Hizmetleri Genel Müdürlüğü. (2012). Engellilerin haklarına ilişkin sözleşme ve ihtiyari protokolü konusunda parlamenterlere yönelik el kitabı. Erişim adresi: https://ailevecalisma.gov.tr/media/5608/parlamenterlere-yonelik-el-kitabii.pdf

T.C. Aile, Çalışma ve Sosyal Politikalar Bakanlığı. (2019). Erişkinler için engellilik ve çocuklar için özel gereksinim değerlendirmesi hakkında yönetmeliklerin uygulanması hakkında genelge. Erişim adresi: https://ailevecalisma.gov.tr/eyhgm/mevzuat/ulusal-mevzuat/genelgeler/eriskinler-icin-engellilik-ve- 
cocuklar-icin-ozel-gereksinim-degerlendirmesi-hakkinda-yonetmeliklerin-uygulanmasi-hakkindagenelge/

T.C. Cumhurbaşkanlığı Strateji ve Bütçe Başkanlığı. (2019). 11. Kalkınma Planı (2019-2023). Erişim adresi: http://www.sbb.gov.tr/wp-content/uploads/2019/07/OnbirinciKalkinmaPlani.pdf

T.C. Kalkınma Bakanlığı. (2015). Onuncu kalkınma planı. Özürlülere Sunulan Hizmetlerin Etkinleştirilmesi Çalışma Raporu, Ankara. Erişim adresi: http://www.sbb.gov.tr/wpcontent/uploads/2018/10/10_OzurlulereSunulanHizmetlerinEtkinlestirilmesiCalismaGurubuRaporu1.pdf

T.C. Milli Eğitim Bakanlığı. (1982). XI. Millî eğitim şurası. Erişim adresi: http://ttkb.meb.gov.tr/meb_iys_dosyalar/2017_09/29165200_11_sura.pdf

T.C. Milli Eğitim Bakanlığı. (1988). XII. Millî eğitim şurası. Erişim adresi: http://ttkb.meb.gov.tr/meb_iys_dosyalar/2017_09/29165252_12_sura.pdf

T.C. Milli Eğitim Bakanlı̆̆ı (2005). Engelliler hakkında kanun. Erişim adresi: https://www.mevzuat.gov.tr/MevzuatMetin/1.5.5378.pdf .

T.C. Milli Eğitim Bakanlığı. (2006). 17. Milli Eğitim Şurası (Raporlar, görüşmeler ve kararlar). Ankara: MEB Yayınları.

T.C. Milli Eğitim Bakanlığı. (2010a). Özel eğitim okullarında özel eğitim hizmetleri uygulamalarının değerlendirilmesi (görme, işitme, ortopedik ve eğitilebilir zihinsel engelliler ilköğretim okulları örneği). Eğitimi Araştırma ve Geliştirme Dairesi Başkanlığı. Ankara. Erişim adresi: http://e-sertifika.gov.tr/earged/earged/Ozel_eg_ok_ozel_eg_hizm_uygu_deg.pdf

T.C. Milli Eğitim Bakanlığı (2010b). 18. Şura kararları. Erişim adresi: http://ttkb.meb.gov.tr/meb_iys_dosyalar/2019_12/10095332_19_sura.pdf

T.C. Milli Eğitim Bakanlığı. (2014). 19. Şura kararları. Erişim adresi: http://ttkb.meb.gov.tr/meb_iys_dosyalar/2019_12/10095332_19_sura.pdf

T.C. Milli Eğitim Bakanlığı. (2017). Eğitim teknolojileri zirvesi. Erişim adresi: https://s3.amazonaws.com/academia.edu.documents/56792586/Fatih_Projesi_ETZ-2017.

T.C. Milli Eğitim Bakanlığı (2019a). Millı̂ Ĕ̆itim istatistikleri örgün eğitim 2018/2019. Erişim adresi: http://sgb.meb.gov.tr/meb_iys_dosyalar/2019_09/30102730_meb_istatistikleri_orgun_egitim_2018_2019.p $\mathrm{df}$

T.C. Milli Eğitim Bakanlığı. (2019b). 2019-2023 Stratejik planı. Erişim adresi: http://www.meb.gov.tr/stratejik_plan/

T.C. Millî Eğitim Bakanlığı (2020a). Ĕ̆itim Bilişim Ağg (EBA). Erişim adresi: http://www.eba.gov.tr/

T.C. Millı̂ Eğitim Bakanlığı (2020b). FATïH Projesi. Erişim adresi: http://fatihprojesi.meb.gov.tr/index.html\#about

T.C. Milli Eğitim Bakanlığı İlköğretim ve Eğitim Kanunu. (2020). 222 sayılı ilköğretim ve eğitim kanunu. Erişim adresi: https://www.mevzuat.gov.tr/MevzuatMetin/1.4.222.pdf

Terzi, Ç. (2005). Uyum sürecinde Türkiye eğitim politikalarının Avrupa Birliği eğitim politikaları doğrultusunda değerlendirilmesi (Doktora tezi). Anadolu Üniversitesi, Eskişehir.

Türkiye Cumhuriyeti. (1982). Türkiye Cumhuriyeti Anayasası. Erişim adresi: https://www.tbmm.gov.tr/anayasa/anayasa_2011.pdf

Türkiye Engelsiz Bilişim Platformu. (2013). FATïH Projesi engelliler çalıştayı raporu. Erişim adresi: https://www.researchgate.net/profile/Gonca_Telli_Yamamoto/publication/289980228_Fatih_Projesi_Gele cegin_Egitimi_Calistay_Raporu/links/5693d1fc08ae820ff07288b2/Fatih-Projesi-Gelecegin-Egitimi- 
Calistay-Raporu.pdf?origin=publication_detail

Uluğ, F. (1985). Açıklamalı eğitim yönetimi sözlüğüu. Ankara: TODAİE

UNDP Türkiye (2020). Sürdürülebilir Kalkınma Amaçları. Erişim adresi: https://www.tr.undp.org/content/turkey/tr/home/sustainable-development-goals.html

UNESCO Küresel Eğitim İzleme Raporu. (2020). UNESCO Küresel Eğitim İzleme Raporu ve Türkiye Analizi. Erişim adresi: https://www.egitimreformugirisimi.org/yayin/unesco-kuresel-egitim-izleme-raporu-veturkiye-analizi/

UNICEF. (2019). Türkiye-UNICEF Ülke İşbirliği Programı 2019 Yıllık Raporu. Erişim adresi: https://www.unicef.org/turkey/media/10451/file/UNICEF\%202019\%20Y1llı\%20Faaliyet\%20Raporu.pdf

Usta, M. E. (2015). Siyasi parti programlarına göre eğitim politikaları. TYB Akademi Dil Edebiyat ve Sosyal Bilimler Dergisi, 5(13), 55-73.

Üçler, C. (2006). 1988-2005 yılları arasında gerçekleştirilen Milli Eğitim Şuraları ve alınan kararların uygulamaları. (Doktora Tezi, Selçuk Üniversitesi Sosyal Bilimler Enstitüsü, Konya). Erişim adresi: http://acikerisimarsiv.selcuk.edu.tr:8080/xmlui/bitstream/handle/123456789/8218/189411.pdf?sequence=1 \&isAllowed=y

Vural, S., Yücesoy, Ş. ve Ünlü, E. (2003). Türkiye'de özel gereksinimli bireylere yönelik hizmetlerin yasal yapılanmasında Avrupa Birliği'ne uyum çabalarının yansımaları. Anadolu Üniversitesi Sosyal Bilimler Dergisi, 3(1), 141-158.

Yamamoto, G. T. (2014). FATïH Projesi engelliler çalıştayı raporu. Erişim adresi: https://okan.edu.tr/uploads/news/fatih-projesi-engelliler-calistay-raporu yayinlandi/fatih_calistay_rapor.pdf

Yıldırım, A. ve Şimşek, H. (2011). Sosyal bilimlerde nitel araştırma yöntemleri. Ankara: Seçkin Yayıncllık.

Yılmaz, B. (2004). Türkiye'de eğitim politikası ve kütüphane. Türk Kütüphaneciler Derneği: Ankara.

Yılmaz, B. ve Dalkıran, Ö. (2012). Türkiye'nin bilim-teknoloji politikalarında kütüphane kurumuna yaklaşım. Bilgi Dünyası, 13(1), 57-81. 


\section{EXTENDED ABSTRACT}

\section{Introduction}

The concept of disability has been handled with different contents and definitions from past to present. Education is one of the most important rights of the individuals with special needs representing a significant part of the population in the world and in our country. Policies need to be developed in order to create components related to the education of the individuals with special needs (access, content, educator quality, educational environment, material, budget, etc.) and to present them in accordance with the principle of equality and include sustainability. To address disability as a social situation, it is possible by determining solution-based goals and creating ways and methods in line with these goals, namely by developing qualified public policies. Education policies are also addressed in this context, and its components are expected to be qualified for those with / without disabilities, who set them up with appropriate goals and can put them into practice. This study, the first in Turkey, which is still in force, demonstrate the approach to the education of individuals with special needs at secondary level, and was carried out to evaluate.

\section{Method}

This study that adopted a descriptive method compared the educational policy documents in primary and secondary education levels which are still in force in Turkey. Educational policy documents examined within this scope are as follows: Republic of Turkey Constitution of 1982, No. 222 Republic of Turkey Ministry of Education Primary Education Law, No. 1739 National Education Basic Law, about 5378 Disability Act, 5580 numbered Private Education Institutions Law, 652 Ministry of National Education of the Organization and Duties of the Decree Law, Decree Law No. 573 on Special Education, Ministry of National Education, Preschool Education and Primary Education Institutions Regulation No. 29072, Regulation on Special Education Services No. 30471, 4.-11. Development Plans, Ministry of National Education 2019-2023 Strategy Plan, 8.-12. and 1719. National Education Councils, Individuals with Special Needs Council, FATIH Project and Workshop on individuals with special needs, 3rd Educational Technologies Summit, 60-65 within the scope of the International Symposium on individuals with Special Needs Free Engagement with International Participation. Problem of the research, "how the first approach to the policy related with individuals with special needs in education at secondary level, which is still in force in Turkey?" The research questions sought to be answered in the study are:

1. How are education policy documents in primary and secondary education levels which are still in force in Turkey address the issue of individuals with special needs?

2. From which perspectives do education policy documents in primary and secondary levels which are still in force in Turkey mainly address the issue of individuals with special needs?

3. Is the approach to issue of individuals with special needs in education policy documents in primary and secondary education levels which are still in force in Turkey applicable and sustainable?

Based upon the research problem and questions, the research hypotheses was formulated as "The concept of individuals with special needs is not adequately addressed in the education policy documents in primary and secondary education level, which are still in force, in Turkey and it is not applicable and sustainable." In the study, the policy documents were evaluated with content analysis techniques and the data of the study were collected based on the literature review. Collected data was interpreted and general perspective was attempted to be created.

\section{Results}

The results of the study show that the concept of individuals with special needs is not sufficiently addressed in Turkish Education Policies. It is thought that there is an imbalance among the policy documents examined, while some documents address the issue of individuals with special needs adequately; the others do not approach holistically and thus, this leave gaps. In addition, the concept of individuals with special needs is "focused on providing financial aid and support", that is, focused on the result, the fact that disability 
is a way of life is overlooked and problems such as access to the process and the process, educator, educational environment, diagnosis and evaluation, families, education program and continuity of all these are not approached holistically. The fact that each component is not handled adequately, that there are points that are incomplete and cannot be properly balanced confirms the research hypothesis.

According to other conclusions inferred from the study, most of the strategies and methods developed for individuals with special needs in policy documents on Turkish education policies are not feasible and sustainable. In most of the policy documents, the importance of the concept of individuals with special needs has been mentioned, but there is not much room for practical and feasible methods of what can be done regarding existing deficiencies and needs. It is believed that this is due to the inability to identify needs well and to gain inclusive and holistic perspectives, as answered in the first questions of the research. Therefore, the results of the research indicate the insufficiency of the level of applicability, which is one of the most important criteria that a modern educational policy should meet, and emphasizes that the examined policy documents show a feature that cannot go beyond the approach.

\section{Conclusion}

The results of the research show that the concept of individuals with special needs is not sufficiently addressed in Turkish education policies, and that there are limitations in applicability and sustainability where it is included. In line with these results, it can be said that some revisions should be made in Turkish education policies. At this point, first of all, it is seen that there is a need to eliminate the confusion related to the concept of individuals with special needs in education policy documents, to analyze the educational needs of individuals with special needs in a qualified manner, to adapt the policy documents adapted from abroad to the structure of our country or to write in original content specially prepared for our society. In addition to this, it is necessary to create / organize policy documents from a holistic perspective, the importance of having individuals with special needs and families as representatives in the committees that make up the policy drafts, the need to create sub-boards that revise and update the documents, to increase the number and frequency of scientific meetings in the universities, to increase the number and frequency of scientific meetings, It is observed that it is beneficial to emphasize the development of academic and applied projects. The study is expected to point to the need and lack of a limited point in the field and to shed light on other academic or applied studies on the subject. 